\title{
A Practical Review of the Biomechanical Parameters Commonly Used in the Assessment of Human Gait
}

\section{Revisión Práctica de los Parámetros Biomecánicos Comúnmente Utilizados en la Evaluación de la Marcha Humana}

\author{
J. C. Arellano-González', H. I. Medellín-Castillo², J. J. Cervantes-Sánchez', A. Vidal-Lesso \\ 'División de Ingenierías Campus Irapuato Salamanca, Universidad de Guanajuato \\ ${ }^{2}$ Facultad de Ingeniería, Universidad Autónoma de San Luis Potosí
}

ABSTRACT

The analysis of human gait is a potential diagnostic instrument for the early and timely identification of pathologies and disorders. It can also supply valuable data for the development of biomedical devices such as prostheses, orthoses, and rehabilitation systems. Although various research papers in the literature have used human gait analyses, few studies have focused on the biomechanical parameters used. This paper presents an extensive review and analysis of the main biomechanical parameters commonly used in the human gait study. The aim is to provide a practical guide to support and understand of the choices and selection of the most appropriate biomechanical parameters for gait analysis. A comprehensive search in scientific databases was conducted to identify, review and analyze the academic work related to human gait analysis. From this search, the main biomechanical parameters used in healthy and pathological gait studies were identified and analyzed. The results have revealed that the spatiotemporal and angular gait parameters are the most used in the assessment of healthy and pathological human gait. 


\section{RESUMEN}

El análisis de la marcha humana es un instrumento potencial de diagnóstico para la identificación oportuna y temprana de patologías y trastornos. También puede proporcionar información valiosa para el desarrollo de dispositivos biomédicos tales como prótesis, órtesis y sistemas de rehabilitación. Aun cuando diversos trabajos de investigación en la literatura han utilizado el análisis de la marcha humana, pocos estudios se han enfocado en analizar los parámetros biomecánicos utilizados. Este trabajo presenta una revisión completa y análisis de los parámetros biomecánicos comúnmente utilizados en el estudio de la marcha humana. El objetivo es proporcionar una guía práctica para apoyar y entender las opciones y selección de los parámetros biomecánicos más adecuados para el análisis de la marcha. Se llevó a cabo una búsqueda exhaustiva en bases de datos científicas para identificar, revisar, y analizar los trabajos de investigación relacionados con el análisis de la marcha humana. A partir de esta búsqueda se identificaron y analizaron los principales parámetros biomecánicos utilizados en estudios de la marcha sana y patológica. Los resultados han revelado que los parámetros espaciotemporales y angulares son los más utilizados en la evaluación de la marcha humana tanto sana como patológica.

PALABRAS CLAVE: Análisis de la marcha, Marcha sana, Marcha patológica, Parámetros de la marcha

\section{Corresponding author}

TO: Juan Carlos Arellano González

INSTITUTION: Universidad de Guanajuato

ADDRESS: Carretera Salamanca-Valle de Santiago

Km. 3.5+1.8, Comunidad de Palo Blanco, C. P. 36885 ,

Salamanca, Guanajuato, México

E-MAIL: carlos.arellano@uaslp.mx

\section{Received:}

8 June 2021

Accepted:

3 September 2021 


\section{INTRODUCTION}

Human gait is a complex process that involves many systems such as bones, joints, muscles, peripheral nerves, spinal cord, and the brain. When one, or some, of these systems fail or present some limitations, the gait process is altered and becomes a pathological gait [1] [2] [3] [4]. Therefore, the analysis of the human gait represents an important instrument for the early and timely identification of pathologies, and a component of follow-up rehabilitation programs [5] [6] [7] [8] [9]. In addition, gait analysis is also important to the design of equipment, devices, rehabilitation systems, prostheses, orthoses, and humanoid robots [10] [11] [12] [13] [14]. Moreover, it can be used in sports science to improve the techniques and performance of athletes. However, such a diagnostic tool requires the use of biomechanical parameters to characterize and evaluate the human gait performance.

Several research works have undertaken the assessment of human gait as a prevention, monitoring, and diagnostic tool. For example, it can be possible to avoid foot ulcers in diabetic patients by increasing foot motion during the intermedia stance phase of the gait cycle ${ }^{[15]}$. Patients with knee osteoarthritis (KOA) often adopt a type of antalgic gait as their disease progresses ${ }^{[16]}$. These patients generally try to protect the damaged knee by biomechanical adaptations that may affect the movement of the joints of the lower extremities and the lower back ${ }^{[17]}{ }^{[18]}$. Gait and balance abnormalities have been described even at early stages in the diagnosis of Alzheimer's ailment ${ }^{[19]}$. Similarly, a fall during gait can be the result of specific characteristics of gait disturbances related to neurological disorders ${ }^{[20]}$. Additionally, it has been observed that robotic gait rehabilitation can improve the biomechanical parameters in chronic hemiplegic patients ${ }^{[21]}$.

Numerous biomechanical parameters have been used in the analysis of the human gait. It was reported that gait patterns and parameters values often vary with the gait velocity ${ }^{[22]}$, a parameter used to identify groups of elderly patients who are at increased risk of death and serious morbidity after cardiac surgery [23]. The spatiotemporal parameters have been related to the gait mechanics of the KOA progression [24] [25] [26] Cadence, stride length, and gait velocity are the main gait parameters that provide a general idea of how well patients can walk ${ }^{[27]}$. In addition, the joint angles of the knee flexion and leg shortening effect parameters are very relevant when analyzing the kinematics of the knee and designing knee prostheses ${ }^{[28]}$.

Over time, the interest in analyzing the performance and characteristics of human gait through biomechanical parameters has increased because human gait alterations can be associated with pathologies known to cause bad body postures and muscle imbalance [19] [29] [30] [31] [32]. However, in the clinical area the gait analysis still relies on the knowledge and experience of the specialist, which represents a certain degree of subjectivity. In addition, few studies have correlated the gait parameters and metrics with clinical problems such as musculoskeletal, neurological, and circulatory problems ${ }^{[33]}$. Furthermore, there is not a comprehensive baseline study to ease the understanding and selection of biomechanical parameters for normal and pathological gait analyses. Therefore, the objective of this research work is to identify and analyze the main biomechanical parameters commonly used in the assessment of human gait.

\section{MATERIALS AND METHODS}

\section{Literature search}

A literature review was carried out to identify research papers dealing with biomechanical parameters used in the human gait analysis. Original articles published in scientific journals indexed in PubMed, Web of Science, Scopus, Science Direct, and Google Scholar, were considered. Although no date of publication limits were used, papers published during the last ten years were mainly considered to identify the latest 
advances. The keywords and mesh terms related to human gait (gait and walking), type of gait (normal, healthy, pathological, hemiplegic, parkinsonian, paraparetic, dancer, apraxic, ataxic, vestibular, equinus, steppe, multisensory deficits, diabetic, prudent, senile, antalgic, dysmetric, Trendelenburg, and claudic), and biomechanical parameters, (temporal, spatial, spatiotemporal, angular, force, strength, kinematic, and kinetic), were used in the search.

In the first search, 380 publications were selected. Next, the title, abstract, and conclusions of each paper were reviewed and the following selection criteria applied: 1) the study should be based on a quantitative analysis of pathological or healthy gait, 2) the study should report the analysis of pathological gaits caused by neurological, musculoskeletal and circulatory problems, 3) the study should use kinematic and kinetic parameters, and other particular parameters according to the case study or pathology, 4) the study should indicate application areas, and 5) priority was given to papers that included the use of three-dimensional digital measurements in gait analysis. The first three criteria were mandatory and the last two were desired. Two independent researchers (authors) conducted searches by applying the criteria and resolving discrepancies. A total of 144 papers were finally selected.

\section{Analysis of the parameters}

In order to identify the most important biomechanical parameters reported in the literature, the selected papers were analyzed in detail. Then a classification of the gait parameters was established according to the following application areas: clinical, sports, and research. Furthermore, the parameters used in the analysis of pathological gaits were identified and classified according to the cause of the pathology as: circulatory, musculoskeletal, and neurological. Finally, set theory was used to systematically analyze the biomechanical parameters, and to facilitate their selection according to the application area. The complete flow chart of the methodology used in this study is shown in Figure 1.

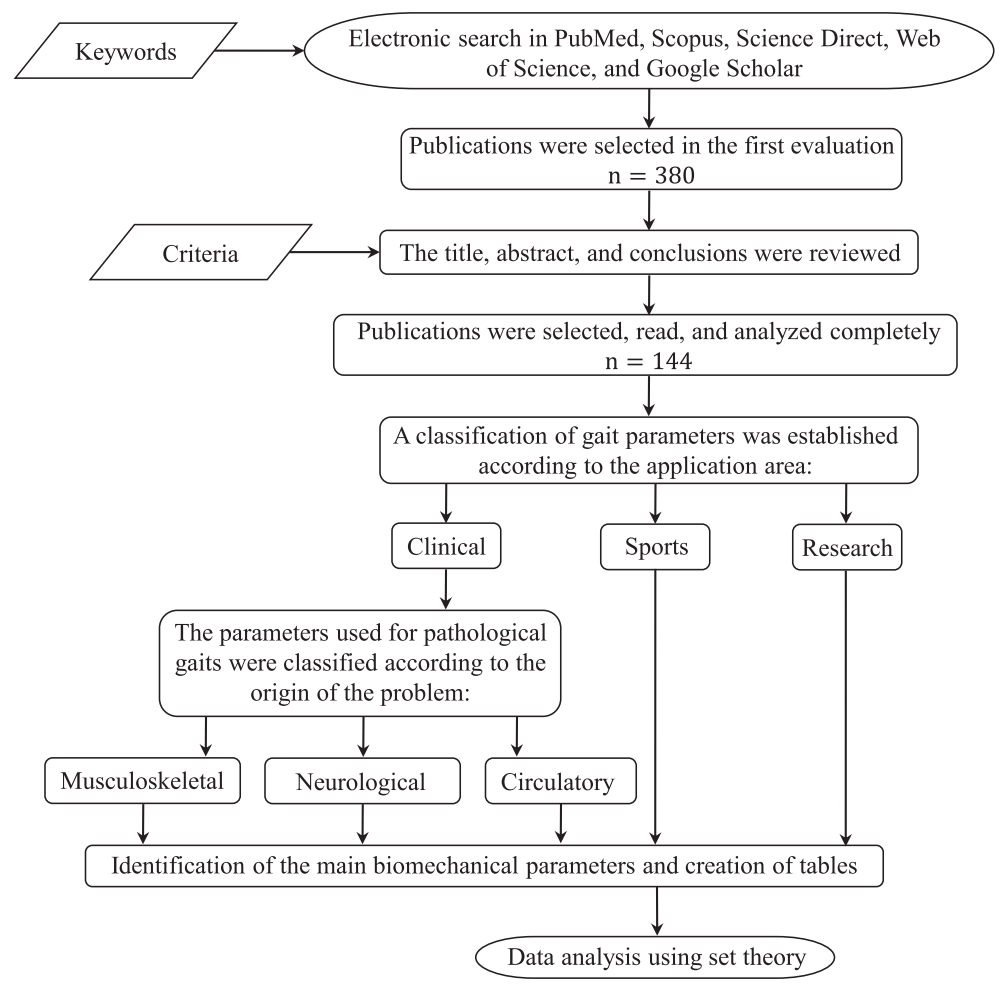

FIGURE 1. Methodology used in the review and analysis of the gait parameters. 


\section{RESULTS AND DISCUSSION}

\section{Demographic and anthropometric data}

The demographic and anthropometric information of the patient is essential when conducting a gait analysis. Table 1 summarizes the demographic and anthropometric parameters reported in the literature.

The demographic data comprises general information about the group of people such as age, gender, place of residence, as well as social or economic characteristics such as occupation, marital status, etc. The most common demographic data used for gait analysis are age and gender.
Table 1 also describes the anthropometric data used in gait analyses. Since computer vision systems, tracking systems, or force plates are commonly used in gait studies, it is important in the collection of anthropometric data to have a robust benchmark that can be used to calibrate the vision system, define the dimensions of the walkway, locate the force plates, etc. ${ }^{[34][35][36]}$. A tendency to decrease the amount of anthropometric information required in gait analyses was also observed [37] [38] [39].

\section{Gait analysis applications}

In general, six main application areas were identified and the percentage of each calculated, Table $2^{\text {[40] [41] [42] }}$ [43] [44] [45] [46] [47] [48] [49] (based on the number of uses in each application area relative to the total number of

TABLE 1. Anthropometric and demographic data required for human gait analysis.

\begin{tabular}{|c|c|c|}
\hline & Data & Description \\
\hline \multirow{12}{*}{ Anthropometric } & Ankle width & $\begin{array}{l}\text { The anthropometric length between the lateral and medial malleolus of } \\
\text { each leg. }\end{array}$ \\
\hline & ASIS width & The horizontal distance between the anteroposterior iliac spines. \\
\hline & Body mass index & A key index for relating weight to height. \\
\hline & Bodyweight & The force that induces the gravity on the human body. \\
\hline & Foot length & The anthropometric length between the heel and the big toe. \\
\hline & Foot width & The anthropometric length between the first and fifth metatarsal heads. \\
\hline & Knee width & $\begin{array}{l}\text { The anthropometric length between the lateral and medial epicondyles of } \\
\text { the femur. }\end{array}$ \\
\hline & Lower leg length & $\begin{array}{l}\text { The anthropometric length between the lateral femoral condyle and the } \\
\text { lateral malleolus. }\end{array}$ \\
\hline & Pelvic height & $\begin{array}{l}\text { The anthropometric length between the superior iliac crest and the } \\
\text { ischium when seated on a stiff chair. }\end{array}$ \\
\hline & Pelvic width & The anthropometric length between the right and left superior iliac crests. \\
\hline & Standing height & The height of a person from foot to head. \\
\hline & Thigh-length & $\begin{array}{l}\text { The anthropometric length between the greater trochanter and the lateral } \\
\text { femoral condyle. }\end{array}$ \\
\hline \multirow{7}{*}{ Demographic } & Age & The time that a person has lived (in years). \\
\hline & Duration of the disease & The elapsed time of having a disease condition (in years). \\
\hline & Gender & Male/Female. \\
\hline & Marital status & The status of a person according to the civil registration. \\
\hline & Employment & The activity where a person is hired to perform a series of specific tasks. \\
\hline & Place of birth & City, state, and country where she/he was born. \\
\hline & Residence & Place where she/he lives. \\
\hline
\end{tabular}


uses). The six application areas were then rearranged into three generic types: clinical (56\%), research (31\%), and sports (13\%) applications; similarly, as reported by Muro-de-la-Herran ${ }^{[33]}$.

TABLE 2. Main applications of gait analysis and proposed classification.

\begin{tabular}{lccc}
\hline $\begin{array}{l}\text { Applications } \\
\text { of gait analysis }\end{array}$ & $\begin{array}{c}\text { Use } \\
(\mathbf{\%})\end{array}$ & $\begin{array}{c}\text { Proposed } \\
\text { classification }\end{array}$ & $\begin{array}{c}\text { Use } \\
(\mathbf{\%})\end{array}$ \\
\hline $\begin{array}{l}\text { Diagnosis } \\
\text { Rehabilitation }\end{array}$ & 25 & Clinical & 56 \\
\hline $\begin{array}{l}\text { Art and entertainment } \\
\begin{array}{l}\text { Ergonomics and } \\
\text { industrial applications }\end{array}\end{array}$ & 913 & Research & 31 \\
$\begin{array}{l}\text { Fundamental and } \\
\text { applied research }\end{array}$ & 9 & & \\
\hline Sports & 13 & Sports & 13 \\
\hline
\end{tabular}

\section{Gait parameters}

In the literature, human gait biomechanical parameters have been classified in several ways. However, all the classifications converge on the use of spatial, temporal, angular, and strength biomechanical parameters. Table 3 presents the biomechanical parameters most used in the literature for gait analysis.In this table, each parameter has been classified, defined, and identified according to the application area.

In order to systematically analyze the biomechanical parameters, set theory is used. Three sets A, B and C are defined and correspond to the parameters used in clinical, research, and sports applications, respectively. The common parameters among the three sets are given by the intersection of the three sets, as shown in Figure 2.

Figure 2 shows that the spatiotemporal parameters predominate in the three application areas. Notice that between the research and the sports sets, and between the research and the clinical sets, there are no common parameters besides those parameters described

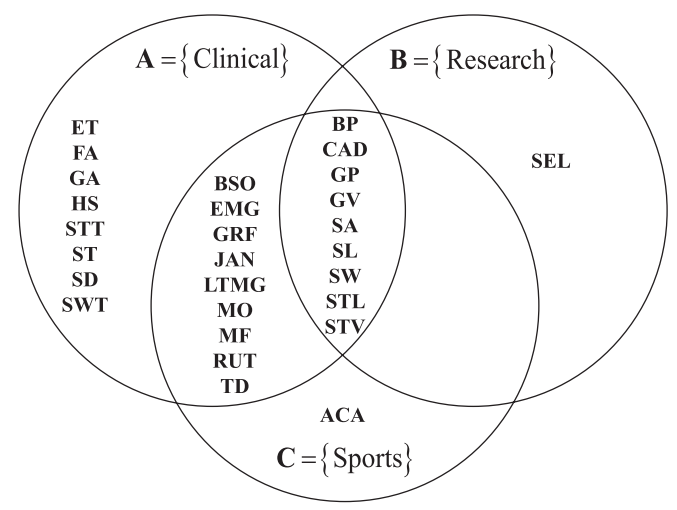

FIGURE 2. Gait parameters used in clinical, sports, and research applications.

by the intersection $\mathbf{A} \cap \mathbf{B} \cap \mathbf{C}$. This suggests that clinical applications make use of most of the biomechanical parameters used in gait analysis.

\section{Clinical gait parameters}

The disability due to gait problems represents approximately $55 \%$ of the total disabilities worldwide ${ }^{[50]}$. These gait disorders may be a consequence of various pathologies, which are known to disturb human motor functions. The most common semiology of the pathological processes that affect human gait is pain, limitation of movement, muscular weakness, and deficit of neurological control ${ }^{[29]}{ }^{[51]}$. Consequently, the study of the characteristics of human gait by means of biomechanical parameters represents a potential tool for the diagnosis, treatment and monitoring of some pathologies. In the literature, many gait pathologies have been analyzed and classified according to the root cause of the functional impairment ${ }^{[27][29]}$ [33] [51]. Based on a preliminary study ${ }^{[52]}$, three large groups of pathologic causes are proposed: neurological, musculoskeletal, and circulatory.

Table 4 synthesizes the clinical gait parameters according to the type of pathology, and presents the parameters used in healthy gait analysis, extending

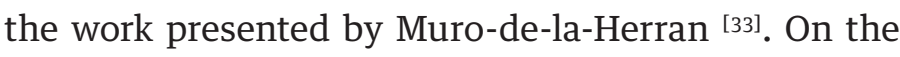
other hand, Table 5 presents the biomechanical parameters and the demographic and anthropometric data used in pathological gait analyses. 
TABLE 3. Description of the biomechanical gait parameters and their applications.

\begin{tabular}{|c|c|c|c|c|c|c|c|c|}
\hline \multirow[b]{2}{*}{$\begin{array}{c}\text { Type of } \\
\text { parameter }\end{array}$} & \multirow[b]{2}{*}{ Reference } & \multirow[b]{2}{*}{$\begin{array}{l}\text { Biomechanical } \\
\text { gait parameters }\end{array}$} & \multirow[b]{2}{*}{ 这 } & \multirow[b]{2}{*}{ 竞 } & \multirow[b]{2}{*}{ Definition } & \multicolumn{3}{|c|}{ Application } \\
\hline & & & & & & $\stackrel{\varrho}{ٍ}$ & 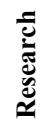 & के \\
\hline \multirow{7}{*}{ Spatial } & 33 & $\begin{array}{l}\text { Accumulated } \\
\text { altitude }\end{array}$ & $\mathrm{ACA}$ & $\mathrm{m}$ & The vertical distance traveled. & & & $x$ \\
\hline & $53-56$ & Height of step & HS & $\mathrm{m}$ & $\begin{array}{l}\text { The movement of the lower } \\
\text { extremities gives a height to the step, } \\
\text { avoiding the drag of the feet. }\end{array}$ & $x$ & & \\
\hline & 28 & $\begin{array}{l}\text { Shortening } \\
\text { effect of the leg }\end{array}$ & SEL & $\%$ & $\begin{array}{l}\text { The natural shortening effect of the } \\
\text { lower limb in the swing phase, } \\
\text { generated by the knee joint to avoid } \\
\text { tripping. }\end{array}$ & & $x$ & \\
\hline & $\begin{array}{l}30,34 \\
53-65\end{array}$ & Step length & SL & $\mathrm{m}$ & $\begin{array}{l}\text { The distance between the placements } \\
\text { of a foot. }\end{array}$ & $x$ & $x$ & $x$ \\
\hline & $30,57-60$ & Step width & SW & $\mathrm{m}$ & $\begin{array}{l}\text { The distance between two equivalent } \\
\text { points of two consecutive footprints. }\end{array}$ & $x$ & $x$ & $x$ \\
\hline & $\begin{array}{l}30,34 \\
53-65\end{array}$ & Stride length & STL & $\mathrm{m}$ & $\begin{array}{l}\text { The distance between the placements } \\
\text { of the same foot. A stride is } \\
\text { equivalent to a complete gait cycle. }\end{array}$ & $x$ & $x$ & $x$ \\
\hline & $53-56$ & $\begin{array}{l}\text { Traveled } \\
\text { distance }\end{array}$ & $\mathrm{TD}$ & $\mathrm{m}$ & The length of the journey traveled. & $x$ & & $x$ \\
\hline \multirow{9}{*}{ Temporal } & $\begin{array}{c}30,34 \\
53-65\end{array}$ & Cadence & CAD & $\begin{array}{c}\text { steps/ } \\
\text { min }\end{array}$ & $\begin{array}{l}\text { The number of steps taken in a time } \\
\text { interval. }\end{array}$ & $x$ & $x$ & $x$ \\
\hline & $53-56$ & Gait autonomy & GA & $\min$ & $\begin{array}{l}\text { The maximum time that a person can } \\
\text { walk, considering the number and } \\
\text { duration of stops. }\end{array}$ & $x$ & & \\
\hline & $\begin{array}{l}30,34 \\
53-65\end{array}$ & Gait phases & GP & $\%$ & Set of divisions of the gait cycle. & $x$ & $x$ & $x$ \\
\hline & $\begin{array}{l}30,34 \\
53-65\end{array}$ & Gait velocity & $\mathrm{GV}$ & $\mathrm{m} / \mathrm{s}$ & $\begin{array}{l}\text { The distance traveled in a defined } \\
\text { time interval. }\end{array}$ & $x$ & $x$ & $x$ \\
\hline & $\begin{array}{l}30,34 \\
53-65\end{array}$ & Stance time & STT & $\mathrm{s}$ & $\begin{array}{l}\text { The time elapsed from the moment } \\
\text { that the heel touches the ground until } \\
\text { the toes are lifted, for each foot. }\end{array}$ & $x$ & & \\
\hline & $\begin{array}{l}30,34 \\
53-60 \\
64-66\end{array}$ & Step time & ST & $\mathrm{s}$ & $\begin{array}{l}\text { The time elapsed between the } \\
\text { placement of one foot and the } \\
\text { placement of the other. }\end{array}$ & $x$ & & \\
\hline & $53-56$ & Stop duration & $\mathrm{SD}$ & $\mathrm{s}$ & $\begin{array}{l}\text { The time in which both feet are on the } \\
\text { ground, without being part of a gait } \\
\text { phase. }\end{array}$ & $x$ & & \\
\hline & $\begin{array}{l}34,53-56 \\
\quad 64-66\end{array}$ & Stride velocity & STV & $\mathrm{m} / \mathrm{s}$ & $\begin{array}{l}\text { The distance traveled in one stride in a } \\
\text { defined time interval. }\end{array}$ & $x$ & $x$ & $x$ \\
\hline & $\begin{array}{l}30,34 \\
53-65\end{array}$ & Swing time & SWT & $\mathrm{s}$ & $\begin{array}{l}\text { The time elapsed from when the foot } \\
\text { is lifted off the ground until it touches } \\
\text { it again, for each foot. }\end{array}$ & $x$ & & \\
\hline
\end{tabular}




\begin{tabular}{|c|c|c|c|c|c|c|c|c|}
\hline \multirow[b]{2}{*}{$\begin{array}{c}\text { Type of } \\
\text { parameter }\end{array}$} & \multirow[b]{2}{*}{ Reference } & \multirow[b]{2}{*}{$\begin{array}{l}\text { Biomechanical } \\
\text { gait parameters }\end{array}$} & \multirow[b]{2}{*}{ ह } & \multirow[b]{2}{*}{$\stackrel{\leftrightarrows}{5}$} & \multirow[b]{2}{*}{ Definition } & \multicolumn{3}{|c|}{ Application } \\
\hline & & & & & & 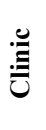 & 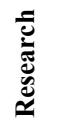 & $\stackrel{n}{\vdots}$ \\
\hline \multirow{4}{*}{ Angular } & $30,53-60$ & $\begin{array}{l}\text { Body posture } \\
\text { (inclination, } \\
\text { symmetry) }\end{array}$ & BP & o & $\begin{array}{l}\text { The direction of a corporal segment } \\
\text { with respect to geometric references } \\
\text { (usually the conventional references). }\end{array}$ & $x$ & $x$ & $x$ \\
\hline & $\begin{array}{c}30,34 \\
53-60 \\
64-66\end{array}$ & $\begin{array}{l}\text { Body segment } \\
\text { orientation }\end{array}$ & BSO & o & $\begin{array}{l}\text { Geometric description of the behavior } \\
\text { of the body referenced to geometric } \\
\text { entities. }\end{array}$ & $x$ & & $x$ \\
\hline & $\begin{array}{l}30,34 \\
53-60 \\
64-66\end{array}$ & Joint angles & JAN & o & $\begin{array}{l}\text { The angle between two members due } \\
\text { to the biomechanical movements of } \\
\text { the joints (hip, knee, ankle). }\end{array}$ & $x$ & & $x$ \\
\hline & $30,53-60$ & Step angle & SA & o & Direction of the foot during the step. & $x$ & $x$ & $\mathrm{x}$ \\
\hline \multirow{4}{*}{ Force } & $\begin{array}{l}30,34 \\
53-60 \\
64-66\end{array}$ & $\begin{array}{l}\text { Ground } \\
\text { reaction forces }\end{array}$ & GRF & $\mathrm{N}$ & $\begin{array}{l}\text { The forces generated on the floor due } \\
\text { to weight and walking. }\end{array}$ & $x$ & & $x$ \\
\hline & $30,53-63$ & Momentum & MO & $\mathrm{N} \cdot \mathrm{m}$ & $\begin{array}{l}\text { Measurement of the rotating potential } \\
\text { that a joint performs against a force to } \\
\text { a specific line. }\end{array}$ & $x$ & & $x$ \\
\hline & $\begin{array}{c}30,34 \\
53-60 \\
64-66\end{array}$ & $\begin{array}{l}\text { Muscle activation } \\
\text { index }\end{array}$ & EMG & $\mathrm{mV}$ & $\begin{array}{l}\text { Electrical activity produced by } \\
\text { muscles. }\end{array}$ & $x$ & & $x$ \\
\hline & $30,53-60$ & Muscle force & MF & $\mathrm{N}$ & $\begin{array}{l}\text { The forces generated in the limbs due } \\
\text { to the action of the contractions and } \\
\text { tractions of the muscles. }\end{array}$ & $x$ & & $x$ \\
\hline \multirow{4}{*}{ Others } & $53-56$ & $\begin{array}{l}\text { Existence of } \\
\text { tremors }\end{array}$ & ET & $\begin{array}{l}\text { Yes/ } \\
\text { No }\end{array}$ & $\begin{array}{l}\text { Presence of disturbances in the form } \\
\text { of oscillation patterns. }\end{array}$ & $x$ & & \\
\hline & $53-56$ & Falls & FA & $\begin{array}{l}\text { Yes/ } \\
\text { No }\end{array}$ & $\begin{array}{l}\text { Any event that precipitates the } \\
\text { individual to the ground against his } \\
\text { will. }\end{array}$ & $x$ & & \\
\hline & $53-56$ & $\begin{array}{l}\text { Long-term } \\
\text { monitoring } \\
\text { of gait }\end{array}$ & LTMG & h, d & $\begin{array}{l}\text { The monitoring history of the gait } \\
\text { behavior in an established period. }\end{array}$ & $x$ & & $x$ \\
\hline & $53-56$ & Route & RUT & - & $\begin{array}{l}\text { Specification of the path walked on } \\
\text { the walkway. This path can be straight } \\
\text { or curve. }\end{array}$ & $x$ & & $x$ \\
\hline
\end{tabular}

\section{ANALYSIS AND DISCUSSION}

\section{Pathological and healthy gaits}

Figure 3 shows the biomechanical parameters used in the assessment and analysis of pathological and healthy (normal) gaits, referred to as set $\mathbf{P}$ and $\mathbf{H}$, respectively. It is observed that in the study of pathological gaits most of the gait parameters reported in the literature are used. The spatiotemporal parameters predominate in the study of both pathological and healthy gaits.
As shown in Table 5, most of the spatiotemporal and angular parameters are used in the analysis of pathological gaits caused by neurological disorders. For instance, senile gait studies all the spatiotemporal and angular parameters except the distance traveled, step angle, and body posture are used. The literature also suggests that the step height parameter is mainly used in the study of prudent and senile pathological gaits, the traveled distance is used in the analysis of dancer gait, and the stop duration temporal parameter is used in the 
TABLE 4. Synthesis of the gait parameters according to the type of pathology.

\begin{tabular}{|c|c|c|c|c|c|c|}
\hline \multirow[b]{3}{*}{$\begin{array}{c}\text { Type of } \\
\text { parameter }\end{array}$} & \multirow[b]{3}{*}{$\begin{array}{c}\text { Gait } \\
\text { parameter }\end{array}$} & \multirow[b]{3}{*}{ Acronym } & \multirow{2}{*}{\multicolumn{3}{|c|}{ Pathological gait according to the origin of the problem }} & \multirow{3}{*}{$\begin{array}{l}\text { Healthy gait } \\
{[34,64-66,144-147]}\end{array}$} \\
\hline & & & & & & \\
\hline & & & $\underset{[19,20,53-56,67-128]}{\text { Neurological }}$ & $\underset{[30,57-60,129-142]}{\text { Musculoskeletal }}$ & $\underset{[61-63,143]}{\text { Circulatory }}$ & \\
\hline \multirow{5}{*}{ Spatial } & Step height & HS & $x$ & & & \\
\hline & Step length & SL & $x$ & $x$ & $x$ & $x$ \\
\hline & Step width & SW & $x$ & $x$ & $x$ & \\
\hline & Stride length & STL & $x$ & $x$ & $x$ & $x$ \\
\hline & Traveled distance & TD & $x$ & & & \\
\hline \multirow{9}{*}{ Temporal } & Cadence & CAD & $x$ & $x$ & $x$ & $x$ \\
\hline & Gait autonomy & GA & $x$ & & & \\
\hline & Gait phases & GP & $x$ & $x$ & $x$ & $x$ \\
\hline & Gait velocity & GV & $x$ & $x$ & $x$ & $x$ \\
\hline & Stance time & STT & $x$ & $x$ & $x$ & $x$ \\
\hline & Step time & ST & $x$ & $x$ & & $x$ \\
\hline & Stop duration & SD & $x$ & & & \\
\hline & Stride velocity & STV & $x$ & & & $x$ \\
\hline & Swing time & SWT & $x$ & $x$ & $x$ & $x$ \\
\hline \multirow{4}{*}{ Angular } & Body posture & $\mathrm{BP}$ & $x$ & $x$ & & \\
\hline & $\begin{array}{c}\text { Body segment } \\
\text { orientation }\end{array}$ & $\mathrm{BSO}$ & $x$ & $x$ & & $x$ \\
\hline & Joint angles & JAN & $x$ & $x$ & & $x$ \\
\hline & Step angle & SA & $x$ & $x$ & & \\
\hline \multirow{4}{*}{ Force } & $\begin{array}{l}\text { Ground } \\
\text { reaction forces }\end{array}$ & GRF & $x$ & $x$ & & $x$ \\
\hline & Momentum & MO & $x$ & $x$ & $x$ & \\
\hline & $\begin{array}{c}\text { Muscle } \\
\text { activation index }\end{array}$ & EMG & $x$ & $x$ & & $x$ \\
\hline & Muscle force & MF & $x$ & $x$ & & \\
\hline \multirow{4}{*}{ Others } & $\begin{array}{l}\text { Existence } \\
\text { of tremors }\end{array}$ & ET & $x$ & & & \\
\hline & Falls & FA & $x$ & & & \\
\hline & $\begin{array}{l}\text { Long-term } \\
\text { monitoring of gait }\end{array}$ & LTMG & $x$ & & & \\
\hline & Route & RUT & $x$ & & & \\
\hline
\end{tabular}

study of Parkinsonian and senile gaits. Likewise, in the study of Parkinsonian and ataxic cerebellar pathological gaits, all angular parameters are used; in contrast, in the analysis of prudent pathological gaits these angular parameters are not used. The joint angles and body segment orientation parameters are commonly used in the analysis of hemiplegic, Parkinsonian, paraparetic, dancer, cerebellar ataxic, equinus, and senile gaits.
On the other hand, the analysis of pathologic gaits caused by musculoskeletal disorders makes use of many spatiotemporal parameters, and all angular parameters. In the antalgic gait analysis, the ground reaction force and the momentum parameters are used, whilst in the study of $d y s$ metric and Trendelenburg gaits the muscle force parameter is used. Regarding other parameters, the gait phases parameter is used in the analysis of musculoskeletal pathologies. 
TABLE 5. Gait parameters and data for pathological and healthy gaits.

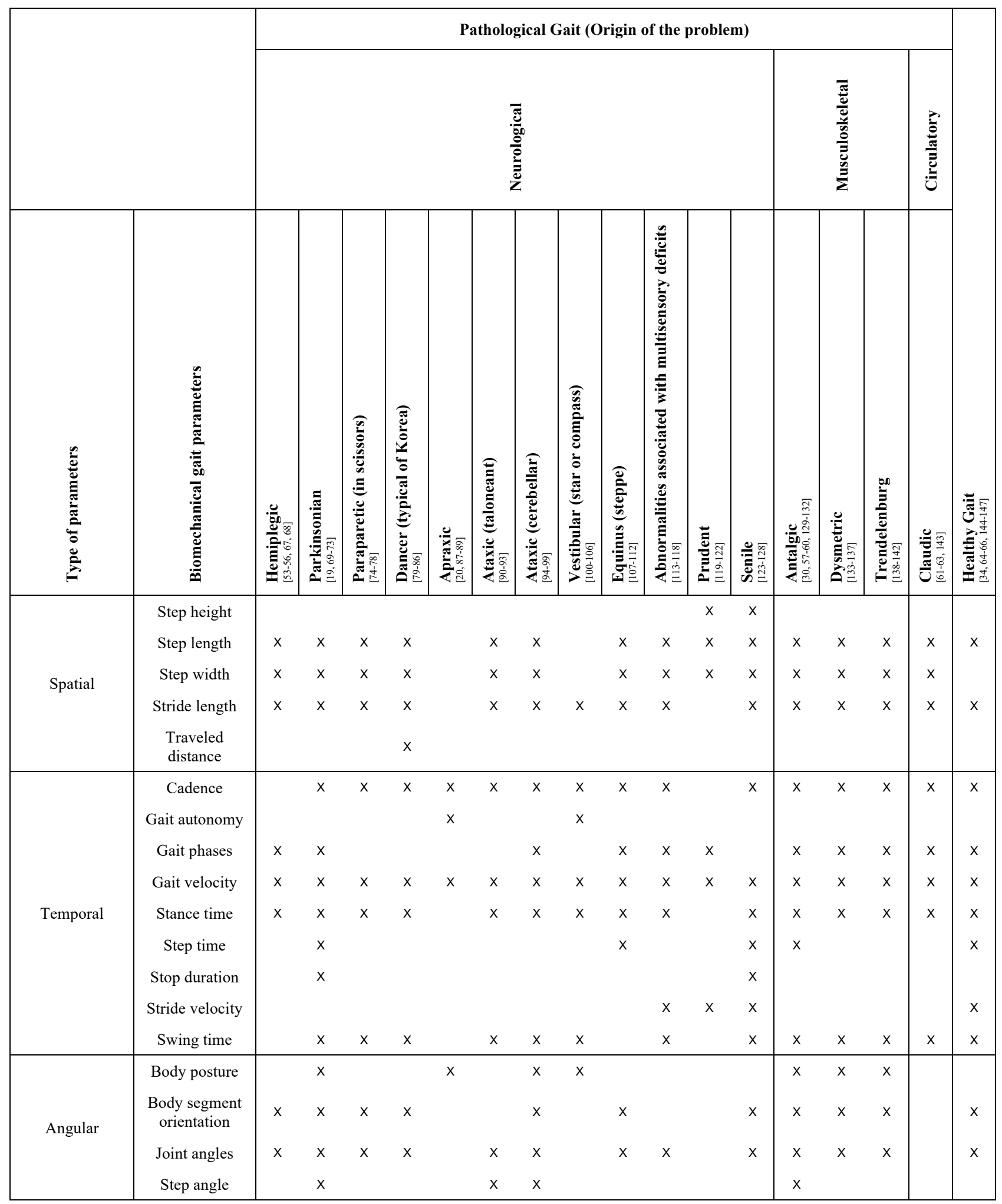




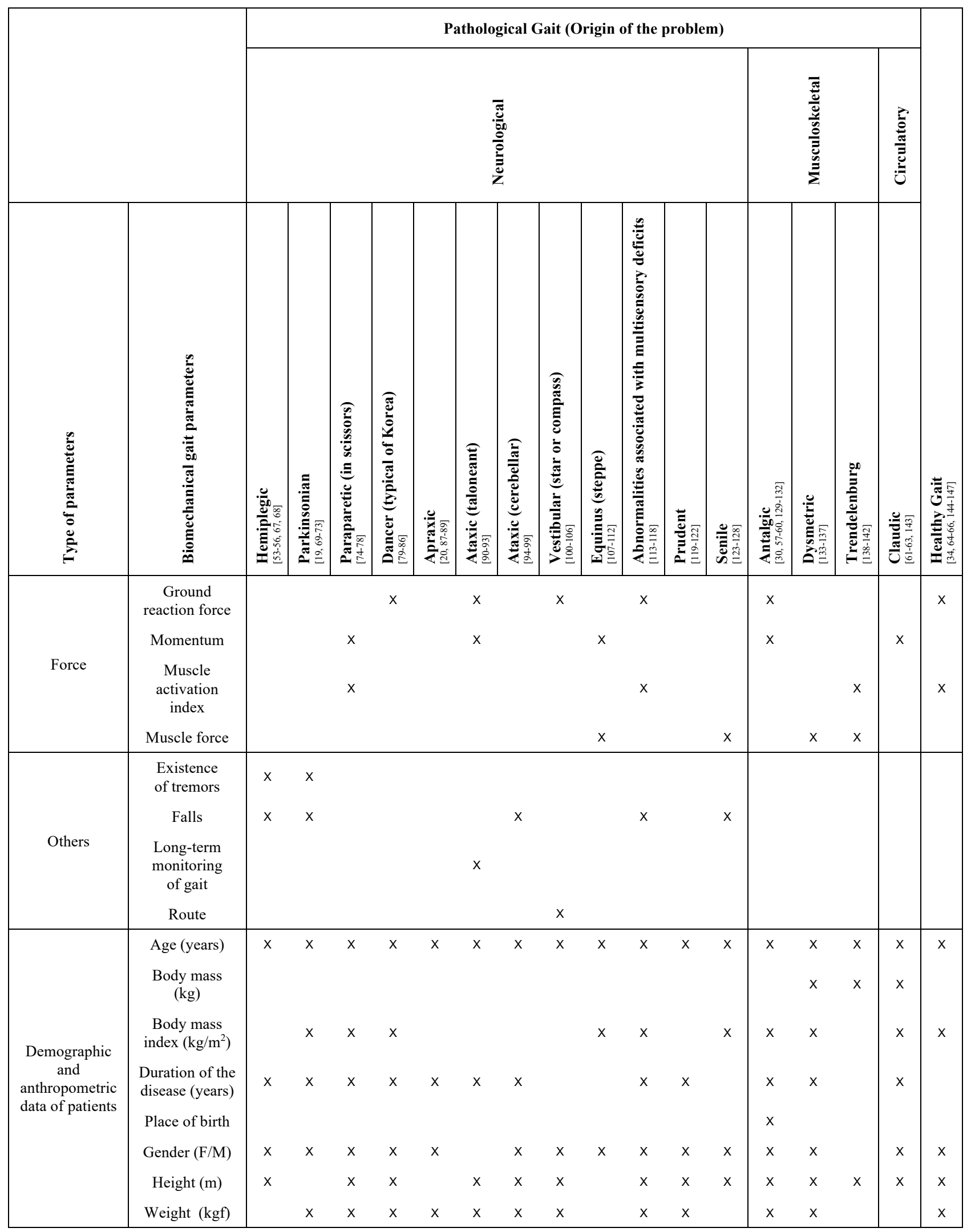




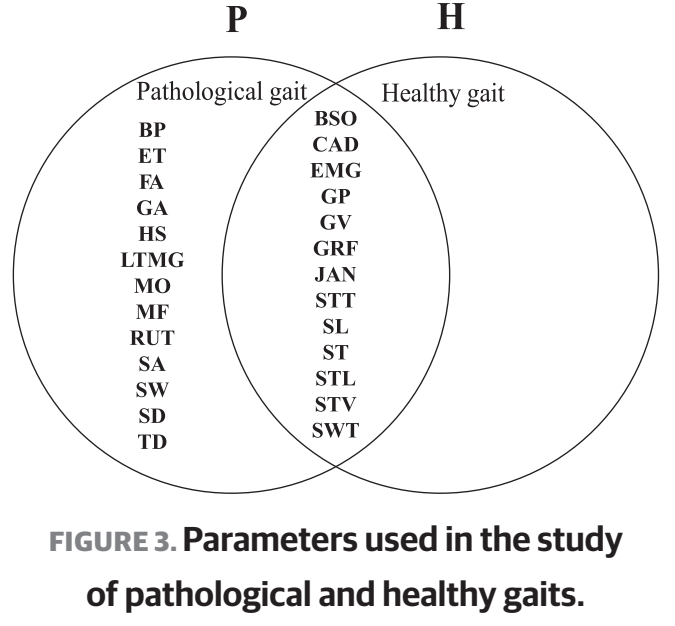

The main circulatory pathological gait reported in the literature is the claudic gait, which requires several spatiotemporal parameters, and the momentum and gait phases parameters. The gait phases parameter is important in order to identify the most critical phase or phases of this pathological gait.

Figure 4 shows the gait parameters used to analyze Musculoskeletal, Neurological, and Circulatory pathologies, referred to as sets $\mathbf{M}, \mathbf{N}$, and $\mathbf{R}$, respectively. In this figure, the common parameters used for these pathologies correspond to the intersection of the three sets. On the other hand, the common parameters between the musculoskeletal and neurological pathologies, besides those given by the intersection: $\mathbf{M} \cap \mathbf{N} \cap \mathbf{R}$, are: muscle activation index, step angle, step time, body posture, muscle strength, joint angles, body segment orientation, and ground reaction forces. It is observed that the analysis of neurological pathologies demands the use of all the parameters, whereas the analysis of circulatory pathologies makes use of the common parameters of the three clinical applications.

\section{Spatial parameters}

Figure 5(a) shows the spatial parameters used in the analysis of pathological and healthy gaits. It is observed that the common parameters used for both pathological and healthy gaits are the step length and stride length. On the other hand, the most common

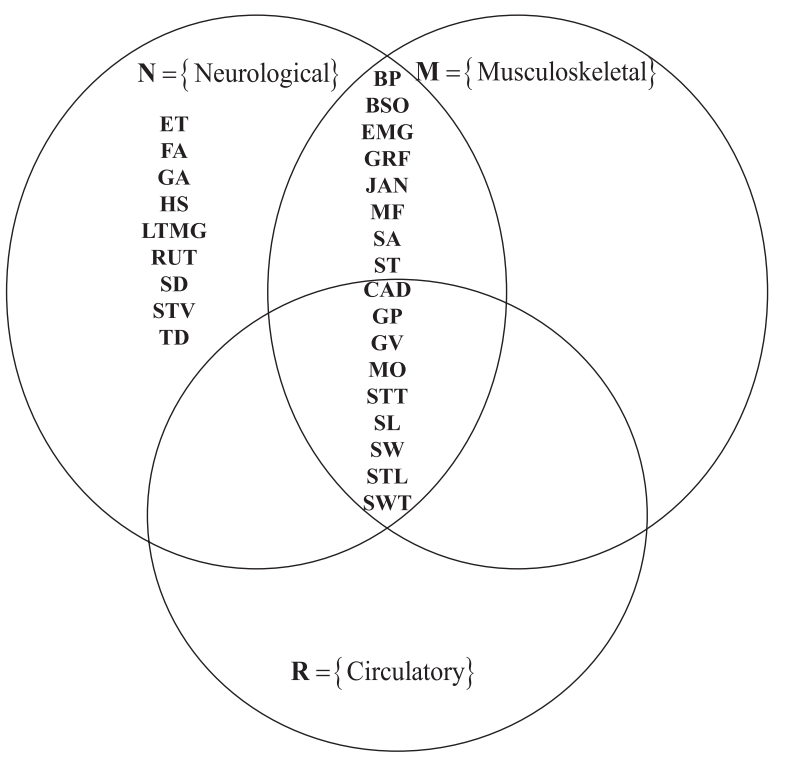

FIGURE 4. Gait parameters used to analyze pathological gaits.

spatial parameters used in pathological gait studies are the step length, step width, and stride length. The traveled distance and height of step are mainly used in the study of pathological gait because of neurological disorders.

\section{Temporal parameters}

Figure 5(b) shows that the gait velocity, cadence, gait phases, swing time, and stance time parameters are the most used temporal parameters, and they correspond to the intersection of the four sets $\mathbf{H} \cap \mathbf{M} \cap \mathbf{N} \cap \mathbf{R}$. The step time is the most common parameter in the study of healthy gaits, and musculoskeletal, and neurological gaits. The stride velocity parameter is used in neurological and healthy gait analyses. The gait autonomy and stop duration parameters are only used in the analysis of pathological gait caused by neurological disorders.

\section{Angular parameters}

Figure 5(c) shows the common angular parameters used in the analysis of healthy, musculoskeletal, and neurological gaits. The literature also suggests that the analysis of pathological gaits due to circulatory prob- 


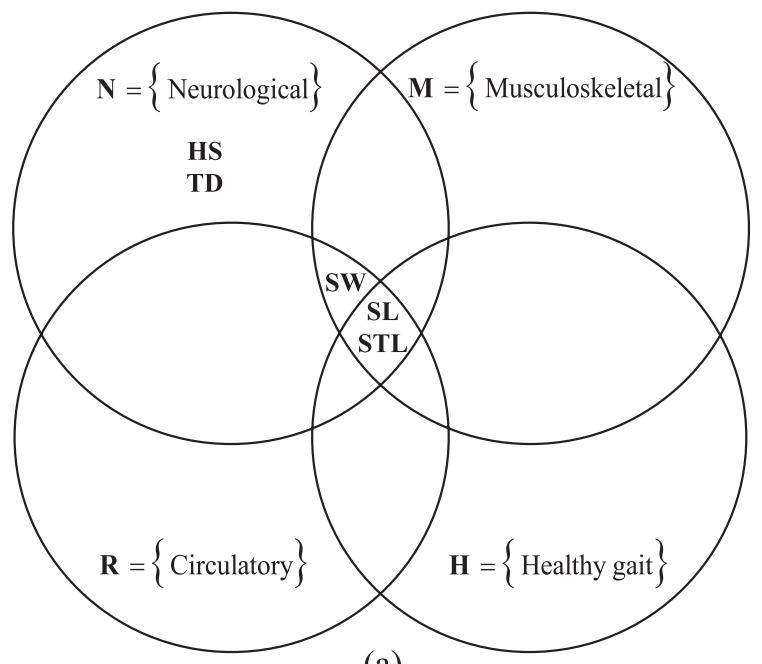

(a)

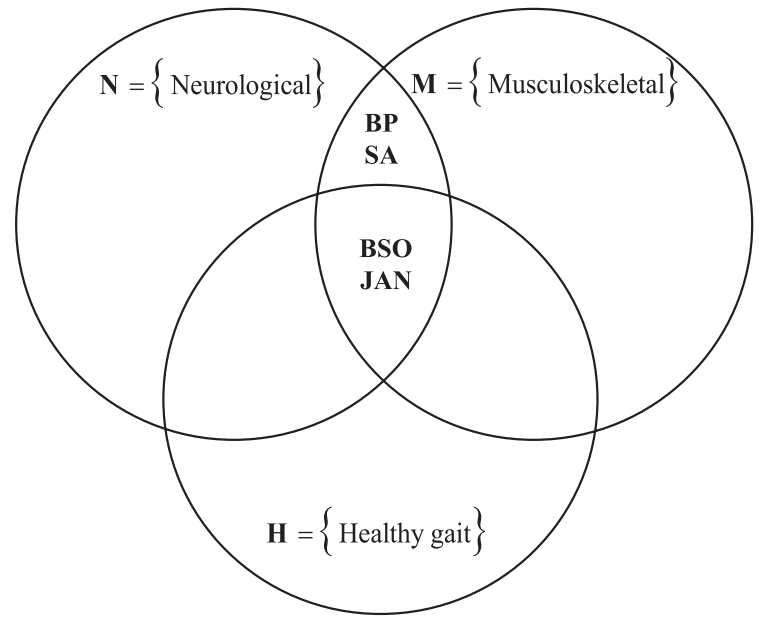

(c)

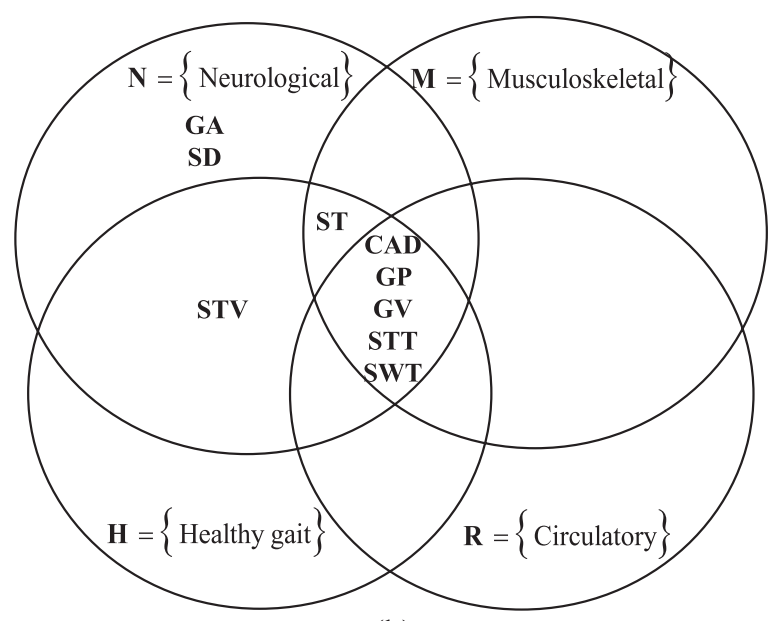

(b)

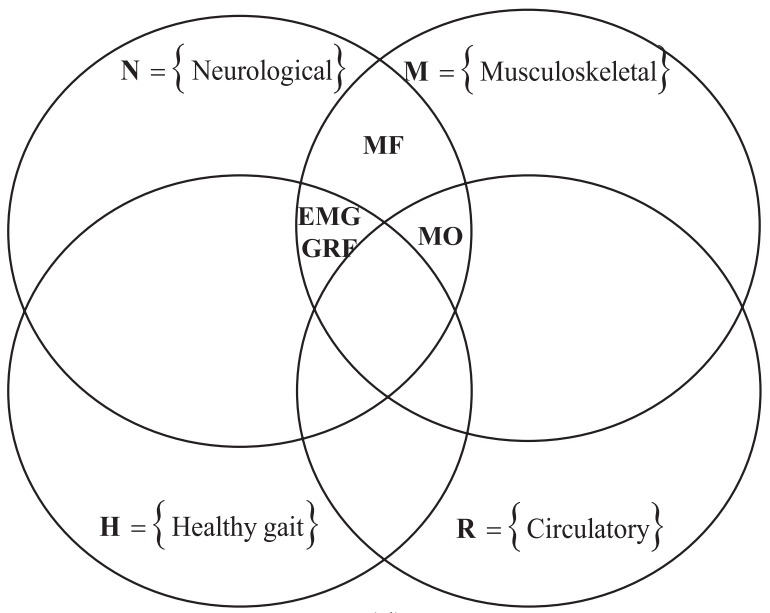

(d)

FIGURE 5. Gait parameters used in the analysis of pathological and healthy gaits:

a) Spatial gait parameters, b) Temporal gait parameters, c) Angular gait parameters, and d) Force gait parameters.

lems does not use angular parameters [31] [32] [33]. The angular parameters $B P$ and $S A$ are mainly used in the assessment of pathological gaits caused by musculoskeletal and neurological problems.

\section{Force parameters}

Figure 5(d) shows that the EMG and GRF are frequent force parameters used in the analysis of musculoskeletal, neurological, and healthy gaits. The $M F$ parameter is mainly used in the analysis of musculoskeletal and neurological pathologies, whilst the $M O$ parameter has only been used in pathological gait studies.

\section{Ranking of parameters}

In order to rank the biomechanical parameters used in the analysis of pathological and healthy gaits, two criteria were defined: 1 ) the relevance of the parameter in the research studies, and 2) the frequency, which was calculated using the following expression:

$$
\boldsymbol{f}=100 n / 144
$$

where $\boldsymbol{f}$ is the frequency percentage, $n$ is the number of times the parameter was used in the selected papers. A normalization process was then considered, given a value of 1 to the most used parameter. Regarding the 
relevance criterion, a value of 1 was given to those parameters with the largest reliability, the most common in different gait analysis (set theory), and the most cited. A relevance value of 0 was assigned to the rest of the parameters. Table 6 shows the results, where it is observed that gait velocity is the most frequently used parameter in the study of human gait because it assesses the functional mobility of an individual and affects his/her gait pattern. Moreover, most of the biomechanical parameters decrease at slower gait velocities and increase at faster gait velocities.

The next most used parameters are cadence, stance time, step length, and stride length. It is also observed that the spatiotemporal and angular biomechanical parameters are the most used in the study of both pathological and healthy gaits. The least popular biomechanical parameters reported in the literature are traveled distance, long-term monitoring of gait, and route, which are specific for the evaluation of dancer, ataxia (taloneant), and vestibular pathologies, respectively. Notice that although these parameters are not very popular parameters, they may be as important as the spatiotemporal parameters for some particular pathologies. The results also revealed that the temporal parameters are the most popular with $37 \%$ of use, followed by the spatial parameters with $24 \%$, the angular parameters with $18 \%$, the force parameters with $8 \%$, and others with $13 \%$.

According to Whittle MW ${ }^{[27]}$, the cadence, gait velocity, and stride length parameters provide a general idea of how well a patient walks. However, the results of this research work suggest that the stance time is also important. For instance, in the study of musculoskeletal-related gait pathologies [57] [60] [140] [142], the stance time is an indicator of the improvement or deterioration of the pathology. On the other hand, although the stride length of both limbs may be the same, the step length of each limb may be different, as reported by Kirtley C ${ }^{[148]}$; for this reason, many studies have considered it relevant. The step width is another rele-

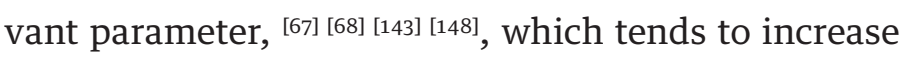
with a balance disorder.

\section{General discussion}

The proposed analysis and classification of the gait parameters represent a general and practical guide to select the parameters for healthy or pathological gait studies. In general, the spatiotemporal and angular parameters are the most used because they allow a detailed and objective study of the human gait. However, other parameters are specific and important for particular pathologies, such as the cartilage thickness ${ }^{[149]}$, which is used in the study of antalgic gait due to knee or hip osteoarthritis. In this work, only the most general pathologies and parameters reported in the literature have been considered.

It was also observed that most of the pathological gait studies $(90 \%)$ reported in the literature were conducted on a walkway instead of an electric treadmill. This is because in the analysis of pathological gaits, the gait velocity is a parameter that depends on the pathology, and the evolution and progress of the patient. In contrast, in the studies related to healthy gait, the gait velocity is usually an independent variable that is defined and varied using an electric treadmill.

The stance time parameter is indicative of the improvement, or severity of pain, in the antalgic gait caused by knee osteoarthritis ${ }^{[131]}$. For example, an increment of the stance time is an indication that the pain experienced by the patient is less and therefore the support of the loading has improved. The use of the step height parameter has not been reported in the literature; however, it can be used in the study of musculoskeletal pathological gaits since it is closely linked to the angular parameter of the knee articulation. The step height parameter may vary due to musculoskeletal pathologies or due to the use of certain footwear, such as the use of high heels, as reported by Arellano ${ }^{[28]}$. 
TABLE 6. General ranking of gait parameters based on their relevance and frequency of use in the literature.

\begin{tabular}{|c|c|c|c|c|c|}
\hline $\begin{array}{c}\text { Gait } \\
\text { parameters }\end{array}$ & $\begin{array}{c}\text { Relevance } \\
\text { value }\end{array}$ & $\begin{array}{c}\% \text { frequency } \\
\text { of use }\end{array}$ & $\begin{array}{l}\text { Frequency } \\
\text { value }\end{array}$ & $\begin{array}{l}\text { Relevance and } \\
\text { frequency value }\end{array}$ & Ranking \\
\hline Gait velocity & 1 & 8.76 & 1.00 & 2.00 & 1 \\
\hline Cadence & 1 & 7.73 & 0.88 & 1.88 & \multirow{4}{*}{2} \\
\hline Stance time & 1 & 7.73 & 0.88 & 1.88 & \\
\hline Step length & 1 & 7.73 & 0.88 & 1.88 & \\
\hline Stride length & 1 & 7.73 & 0.88 & 1.88 & \\
\hline Step width & 1 & 7.22 & 0.82 & 1.82 & 3 \\
\hline Joint angles & 1 & 6.70 & 0.76 & 1.76 & \multirow{2}{*}{4} \\
\hline Swing time & 1 & 6.70 & 0.76 & 1.76 & \\
\hline Gait phases & 1 & 5.67 & 0.65 & 1.65 & 5 \\
\hline Ground reaction forces & 1 & 3.09 & 0.35 & 1.35 & 6 \\
\hline Muscle activation index & 1 & 2.06 & 0.24 & 1.24 & 7 \\
\hline Body segment orientation & 0 & 5.67 & 0.65 & 0.65 & 8 \\
\hline Body posture & 0 & 3.61 & 0.41 & 0.41 & 9 \\
\hline Falls & 0 & 2.58 & 0.29 & 0.29 & \multirow{3}{*}{10} \\
\hline Momentum & 0 & 2.58 & 0.29 & 0.29 & \\
\hline Step time & 0 & 2.58 & 0.29 & 0.29 & \\
\hline Muscle force & 0 & 2.06 & 0.24 & 0.24 & \multirow{3}{*}{11} \\
\hline Step angle & 0 & 2.06 & 0.24 & 0.24 & \\
\hline Stride velocity & 0 & 2.06 & 0.24 & 0.24 & \\
\hline Existence of tremors & 0 & 1.03 & 0.12 & 0.12 & \multirow{4}{*}{12} \\
\hline Gait autonomy & 0 & 1.03 & 0.12 & 0.12 & \\
\hline Step height & 0 & 1.03 & 0.12 & 0.12 & \\
\hline Stop duration & 0 & 1.03 & 0.12 & 0.12 & \\
\hline Long-term monitoring of gait & 0 & 0.52 & 0.06 & 0.06 & \multirow{3}{*}{13} \\
\hline Route & 0 & 0.52 & 0.06 & 0.06 & \\
\hline Traveled distance & 0 & 0.52 & 0.06 & 0.06 & \\
\hline
\end{tabular}

The leg shortening effect parameter is also an important parameter that has been mentioned qualitatively in some works, but a complete quantitative study has not been reported yet. This leg shortening effect may be relevant when designing knee prostheses.

Finally, it can be said that most of the research works related to pathological gait have been conducted considering only intrinsic conditions such as age, gender, weight, etc., or the type of pathology. Few studies have considered both intrinsic and extrinsic conditions such as climbing slopes, walking with a front-load, using a certain type of footwear, walking whilst texting or calling by cell phone, etc.

\section{CONCLUSIONS}

A review and analysis of the main biomechanical gait parameters used in the literature to study pathological and healthy gaits has been presented. The gait parameters have been identified and classified according to the type of physical quantity (spatial, temporal, angular, force and others) and according to the application 
area (clinical, sports and research). The clinical applications were subdivided according to the pathological disorder into neurological, musculoskeletal, and circulatory applications, being the neurological area the one that uses most of the gait parameters. The overall most common parameters are body posture, cadence, gait phases, gait velocity, step angle, step length, step width, stride length, and stride velocity. Finally, it can be said that the results presented in this investigation can be used as a practical guide to identify and select the main biomechanical parameters commonly used in the analysis and monitoring of human gaits under pathological or normal conditions.

\section{AUTHOR CONTRIBUTIONS}

The four authors participated in all the stages of the project from the conceptualization to the writing of the manuscript. In this sense, each author participated in the following roles: J.C.A.G. contributed to the conceptualization, data curation, formal analysis, investigation, methodology, visualization, and writing the original draft. H.I.M.C. contributed to the conceptualization, formal analysis, investigation, project administration, resources, supervision, validation, writing original draft, and writing, reviewing, and editing the final version. J.J.C.S. contributed to the conceptualization, validation, visualization, and writing, reviewing, and editing the final version. A.V.L. contributed to the conceptualization, validation, and writing, reviewing, and editing the final version.

\section{ACKNOWLEDGMENTS}

The first author acknowledges the Program for Professional Development of Academics (PRODEP) of the Secretary of Public Education (SEP) of Mexico, for the scholarship provided during his Ph.D. studies. The authors would like to thank Professor Jonathan Corney from University of Edinburgh for his help and advice to this work.

\section{CONFLICTS OF INTEREST}

The authors do not report any conflict of interest. 


\section{REFERENCES}

[1] Detrembleur C, van den Hecke A, Dierick F. Motion of the body centre of gravity as a summary indicator of the mechanics of human pathological gait. Gait Posture [Internet]. 2000;12(3):243250. Available from: https://doi.org/10.1016/S0966-6362(00)00081-3

[2] Khokhlova M, Migniot C, Morozov A, Sushkova O, et al. Normal and pathological gait classification LSTM model. Artif Intell Med [Internet]. 2019;94:54-66. Available from: https://doi.org/10.1016/j.artmed.2018.12.007

[3] Moreno-Hernández A, Rodríguez-Reyes G, Quiñones-Urióstegui I, Núñez-Carrera L, et al. Temporal and spatial gait parameters analysis in non-pathological Mexican children. Gait Posture [Internet]. 2010;32(1):78-81. Available from: https://doi.org/10.1016/j.gaitpost.2010.03.010

[4] Bruening DA, Ridge ST. Automated event detection algorithms in pathological gait. Gait Posture [Internet]. 2014;39(1):472-477. Available from: https://doi.org/10.1016/j.gaitpost.2013.08.023

[5] Phinyomark A, Osis ST, Hettinga BA, Kobsar D, et al. Gender differences in gait kinematics for patients with knee osteoarthritis. BMC Musculoskelet Disord [Internet]. 2016;17:157. Available from: https://doi.org/10.1186/s12891-016-1013-z

[6] Smith Y, Louw Q, Brink Y. The three-dimensional kinematics and spatiotemporal parameters of gait in 6-10 years old typically developed children in the cape metropole of South Africa - a pilot study. BMC Pediatr [Internet]. 2016;16:200. Available from: https://doi.org/10.1186/s12887-016-0736-1

[7] Washabaugh EP, Augensteina TE, Krishnan C. Functional resistance training during walking: Mode of application differentially affects gait biomechanics and muscle activation patterns. Gait Posture [Internet]. 2020;75:129-136. Available from: https://doi.org/10.1016/j.gaitpost.2019.10.024

[8] Simon SR. Quantification of human motion: gait analysis-benefits and limitations to its application to clinical problems. J Biomech [Internet]. 2004;37(12):1869-1880. Available from: https://doi.org/10.1016/j.jbiomech.2004.02.047

[9] Naili JE, Wretenberg P, Lindgren V, Iversen MD, et al. Improved knee biomechanics among patients reporting a good outcome in knee-related quality of life one year after total knee arthroplasty. BMC Musculoskelet Disord [Internet]. 2017;18:122. Available from: https://doi.org/10.1186/s12891-017-1479-3

[10] Hussain S, Xie SQ, Jamwal PK. Control of a robotic orthosis for gait rehabilitation. Robot Auton Syst [Internet]. 2013;61(9):911-919. Available from: https://doi.org/10.1016/j.robot.2013.01.007

[11] Khas KS, Pandey PM, Ray AR. Development of an orthosis for simultaneous three-dimensional correction of clubfoot deformity. Clin Biomech [Internet]. 2018;51:67-75. Available from: https://doi.org/10.1016/i.clinbiomech.2017.12.002

[12] Arnez-Paniagua V, Rifaï H, Amirat Y, Ghedira M, et al. Adaptive control of an actuated ankle foot orthosis for paretic patients. Control Eng Pract [Internet]. 2019;90:207-220. Available from: https://doi.org/10.1016/j.conengprac.2019.06.003

[13] Kobayashi T, Orendurff MS, Singer ML, Gao F, et al. Contribution of ankle-foot orthosis moment in regulating ankle and knee motions during gait in individuals post-stroke. Clin Biomech [Internet]. 2017;45:9-13. Available from: https://doi.org/10.1016/j.clinbiomech.2017.04.002
[14] Segal AD, Orendurff MS, Klute GK, McDowell ML, et al. Kinematic and kinetic comparisons of transfemoral amputee gait using C-Leg ${ }^{\circledR}$ and Mauch SNS ${ }^{\circledR}$ prosthetic knees. J Rehabil Res Dev [Internet]. 2006;43(7):857-870. Available from: https://doi.org/10.1682/jirrd.2005.09.0147

[15] Amemiya A, Noguchi H, Oe M, Ohashi Y, et al. Elevated plantar pressure in diabetic patients and its relationship with their gait features. Gait Posture [Internet]. 2014;40(3):408-414. Available from: https://doi.org/10.1016/j.gaitpost.2014.05.063

[16] Bejek Z, Paróczai R, Illyés Á, Kocsis L, et al. Gait parameters of patients with osteoarthritis of the knee joint. Phys Educ Sport [Internet]. 2006;4(1): 9-16. Available from: http://facta.junis.ni.ac. rs/pe/pe2006/pe2006-02.pdf

[17] Andriacchi TP, Galante JO, Fermier RW. The influence of total knee replacement design on walking and stair-climbing. J Bone Joint Surg Am [Internet]. 1982;64(9):1328-1335. Available from: https://doi.org/10.2106/00004623-198264090-00008

[18] Gök H, Ergin S, Yavuzer G. Kinetic and kinematic characteristic of gait in patients with medial knee arthrosis. Acta Orthop Scand [Internet]. 2002;73(6): 647-652. Available from: https://doi.org/10.3109/17453670209178029

[19] Tangen GG, Bergland A, Engedal K, Mengshoel AM. The importance of parkinsonian signs for gait and balance in patients with Alzheimer's disease of mild degree. Gait Posture [Internet]. 2017;51:159-161. Available from: https://doi.org/10.1016/j.gaitpost.2016.10.00

[20] Axer H, Axer M, Sauer H, Witte OW, et al. Falls and gait disorders in geriatric neurology. Clin Neurol Neurosurg [Internet]. 2010;112(4):265-274. Available from: https://doi.org/10.1016/j.clineuro.2009.12.015

[21] Wallard L, Dietrich G, Kerlirzin Y, Brendin J. Effects of robotic gait rehabilitation on biomechanical parameters in the chronic hemiplegic patients. Clin Neurophysiol [Internet]. 2015;45(3):215 -219. Available from: https://doi.org/10.1016/j.neucli.2015.03.002

[22] Van Der Krogt M, Doorenbosch C, Becher J, Harlaar J. Po80 Gait patterns vary with walking speed. Gait Posture [Internet]. 2008;28(2S): S49-S118. Available from: https://doi.org/10.1016/S0966-6362(08)70149-8

[23] Afilalo J, Eisenberg MJ, Morin JF, Bergman H, et al. Gait Speed as an Incremental Predictor of Mortality and Major Morbidity in Elderly Patients Undergoing Cardiac Surgery. J Am Coll Cardiol [Internet]. 2010;56(20):1668-1676. Available from: https://doi.org/10.1016/j.jacc.2010.06.039

[24] Mills K, Hunt MA, Ferber R. Biomechanical Deviations During Leve Walking Associated With Knee Osteoarthritis: A Systematic Review and Meta-Analysis. Arthritis Care Res [Internet]. 2013;65(10):16431665. Available from: https://doi.org/10.1002/acr.22015

[25] Duffell LD, Jordan SJ, Cobb JP, McGregor AH. Gait adaptations with aging in healthy participants and people with knee-joint osteoarthritis. Gait Posture [Internet]. 2017;57:246-251. Available from: https://doi.org/10.1016/j.gaitpost.2017.06.015

[26] Andriacchi TP, Mündermann A. The role of ambulatory mechanics in the initiation and progression of knee osteoarthritis. Curr Opin Rheumatol [Internet]. 2006;18(5):514-518. Available from: https://doi.org/10.1097/01.bor.0000240365.16842.4e 
[27] Whittle MW. Clinical gait analysis: A review. Hum Mov Sci [Internet]. 1996;15(3):369-387. Available from: https://doi.org/10.1016/0167-9457(96)00006-1

[28] Arellano-González JC, Medellín-Castillo HI, Cárdenas-Galindo JA. Analysis of the kinematic variation of human gait under different walking conditions using computer vision. RMIB [Internet]. 2017;38(2):437-457. Available from: http://dx.doi.org/10.17488/rmib.38.2.2

[29] Perry J, Burnfield JM. Gait analysis: Normal and pathological function. 2nd ed., New Jersey: SLACK Incorporated; 2010. 551p.

[30] Hicks GE, Sions JM, Coyle PC, Pohlig RT. Altered spatiotemporal characteristics of gait in older adults with chronic low back pain. Gait Posture [Internet]. 2017;55:172-176. Available from: https://doi.org/10.1016/j.gaitpost.2017.04.02

[31] Allet L, Armand S, de Bie RA, Pataky Z, et al. Gait alterations of diabetic patients while walking on different surfaces. Gait Posture [Internet]. 2009;29(3):488-493. Available from: https://doi.org/10.1016/j.gaitpost.2008.11.012

[32] Mummolo C, Mangialardi L, Kim JH. Quantifying Dynamic Characteristics of Human Walking for Comprehensive Gait Cycle. J Biomech Eng [Internet]. 2013;135(9): (9): 091006. Available from: https://doi.org/10.1115/1.4024755

[33] Muro-de-la-Herran A, Garcia-Zapirain B, Mendez-Zorrilla A. Gait Analysis Methods: An Overview of Wearable and Non-Wearable Systems, Highlighting Clinical Applications. Sensors [Internet]. 2014;14(2):3362-3394. Available from: https://doi.org/10.3390/s140203362

[34] Kadaba MP, Ramakrishnan HK, Wootten ME. Measurement of lower extremity kinematics during level walking. J Orthop Res [Internet]. 1990;8(3):383-392. Available from: https://doi.org/10.1002/jor.1100080310

[35] Frigo C, Rabuffetti M, Kerrigan DC, Deming LC, et al. Functionally oriented and clinically feasible quantitative gait analysis method. Med Biol Eng Comput [Internet]. 1998;36(2):179-185. Available from: https://doi.org/10.1007/BF02510740

[36] van den Bogert AJ, Geijtenbeek T, Even-Zohar O, Steenbrink F, et al. A real-time system for biomechanical analysis of human movement and muscle function. Med Biol Eng Comput [Internet].

2013;51(10):1069-1077. Available from: https://doi.org/10.1007/s11517-013-1076-z

[37] Leardini A, Sawacha Z, Paolini G, Ingrosso S, et al. A new anatomically based protocol for gait analysis in children. Gait Posture [Internet]. 2007;26(4):560-571. Available from: https://doi.org/10.1016/j.gaitpost.2006.12.018

[38] Sholukha V, Bonnechere B, Salvia P, Moiseev F, et al. Model-based approach for human kinematics reconstruction from markerless and marker-based motion analysis systems. J Biomech [Internet]. 2013;46(14):2363-2371. Available from: https://doi.org/10.1016/i.jbiomech.2013.07.037

[39] Benedetti MG, Catani F, Leardini A, Pignotti E, et al. Data management in gait analysis for clinical applications. Clin Biomech [Internet]. 1998;13(3):204-215. Available from: https://doi.org/10.1016/\$0268-0033(97)00041-7

[40] Motek. Applications for human movement research and

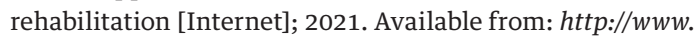
motekmedical.com/
[41] Baker R. Gait analysis methods in rehabilitation. J NeuroEng Rehabil [Internet]. 2006;3:4. Available from: https://doi.org/10.1186/1743-0003-3-4

[42] Khan T, Grenholm P, Nyholm D. Computer Vision Methods for Parkinsonian Gait Analysis: A Review on Patents. Recent Pat Biomed Eng [Internet]. 2013;6(2):97-108. Available from: https://doi.org/10.2174/1874764711306020004

[43] Ali A, Sundaraj K, Ahmad B, Ahmad N, et al. Gait disorder rehabilitation using vision and non-vision based sensors: A systematic review. Bosn J of Basic Med Sci [Internet]. 2012;12(3):193-202. Available from: https://doi.org/10.17305/bjbms.2012.2484

[44] Federolf PA, Boyer KA, Andriacchi TP. Application of principal component analysis in clinical gait research: identification of systematic differences between healthy and medial kneeosteoarthritic gait. J Biomech [Internet]. 2013;46(13):2173-2178. Available from: https://doi.org/10.1016/j.jbiomech.2013.06.032

[45] Stancic I, Supuk TG, Bonkovic M. New Kinematic Parameters for Quantifying Irregularities in the Human and Humanoid Robot Gait. Int J Adv Robot [Internet]. 2017;9(5):1-8. Available from: https://doi.org/10.5772/54563

[46] CAD. Engineering Services, Solutions and services offering [Internet]. 2021; Available from: http://www.cadengineering.co.in/

[47] Bartlett R. Introduction to Sport in Biomechanics: Analyzing Human Movement Patterns. 2nd ed. New York: Taylor \& Francis Group; 2007. 292p.

[48] Huston RL. Principles of biomechanics. 1st ed. NW: Taylor \& Francis Group; 2009.

[49] Knudson D. Fundamentals of biomechanics. 2nd ed. California: Springer; 2007. 319p.

[50] Center for Disease Control and Prevention. National Center for Health Statistics [Internet]. 2021; Available from: https://www.cdc. gov/nchs/index.htm

[51] Sánchez-Lacuesta J, Prat Pastor JM, Hoyos Fuentes JV, Viosca Herrero E, et al. Biomecánica de la marcha humana patológica. 2nd ed. España: Instituto de Biomecánica de Valencia; 1999. 444p.

[52] Arellano-González JC, Medellín-Castillo HI, Cervantes-Sánchez JJ. Identification and analysis of the biomechanical parameters used for the assessment of normal and pathological gait: A literature review. Proceedings of the ASME 2019 International Mechanical Engineering Congress and Exposition. Volume 3: Biomedical and Biotechnology Engineering [Internet]. Salt Lake City: ASME; 2019:11-17. Available from: https://doi.org/10.1115/IMECE2019-10140

[53] Granat MH, Maxwell DJ, Bosch CJ, Ferguson AC, et al. A body-worn gait analysis system for evaluating hemiplegic gait. Med Eng Phys [Internet]. 1995;17(5):390-394. Available from: https://doi.org/10.1016/1350-4533(95)97321-F

[54] Di Nardo F, Mengarelli A, Malavolta M, Strazza A, et al. Ankle muscle co-contractions in Winters I hemiplegic children during gait. Gait Posture [Internet]. 2017;57(S3):4-5. Available from: https://doi.org/10.1016/j.gaitpost.2017.07.051 
[55] Gross R, Leboeuf F, Hardouin JB, Perrouin-Verbe B, et al. Does muscle coactivation influence joint excursions during gait in children with and without hemiplegic cerebral palsy? Relationship between muscle coactivation and joint kinematics. Clin Biomech [Internet]. 2015;30(10):1088-1093. Available from: https://doi.org/10.1016/j.clinbiomech.2015.09.001

[56] Hussein ZA, Abd-Elwahab MS, El-Shennawy SAW. Effect of arm cycling on gait of children with hemiplegic cerebral palsy. Egypt J Med Hum Genet [Internet]. 2014;15(3):273-279. Available from: https://doi.org/10.1016/j.ejmhg.2014.02.008

[57] de Kruijf M, Verlinden VJA, Huygen FJPM, Hofman A, et al. Chronic joint pain in the lower body is associated with gait differences independent from radiographic osteoarthritis. Gait Posture [Internet]. 2015;42(3):354-359. Available from: https://doi.org/10.1016/j.gaitpost.2015.06.193

[58] Vickers J, Reed A, Decker R, Conrad BP, et al. Effect of investigator observation on gait parameters in individuals with and without chronic low back pain. Gait Posture [Internet]. 2015;53:35-40. Available from: https://doi.org/10.1016/j.gaitpost.2017.01.002

[59] Stewart S, Morpeth T, Dalbeth N, Vandal AC, et al. Foot-related pain and disability and spatiotemporal parameters of gait during selfselected and fast walking speeds in people with gout: A two-arm cross sectional study. Gait Posture [Internet]. 2016;44:18-22. Available from: https://doi.org/10.1016/i.gaitpost.2015.11.004

[60] Phillips A, McClinton S. Gait deviations associated with plantar heel pain: A systematic review. Clin Biomech [Internet]. 2017;42:55-64. Available from: https://doi.org/10.1016/i.clinbiomech.2016.12.012

[61] Koutakis P, Pipinos II, Myers SA, Stergiou N, et al. Joint torques and powers are reduced during ambulation for both limbs in patients with unilateral claudication. J Vasc Surg [Internet]. 2010;51(1):8088. Available from: https://doi.org/10.1016/j.jvs.2009.07.117

[62] Wurdeman SR, Koutakis P, Myers SA, Johanning JM, et al. Patients with peripheral arterial disease exhibit reduced joint powers compared to velocity-matched controls. Gait Posture [Internet]. 2012;36(3):506-509. Available from: https://doi.org/10.1016/j.gaitpost.2012.05.004

[63] Scherer SA, Bainbridge JS, Hiatt WR, Regensteiner JG. Gait characteristics of patients with claudication. Arch Phys Med Rehabil [Internet]. 1998;79(5):529-531. Available from: https://doi.org/10.1016/50003-9993(98)90067-3

[64] Pérez-Orive J, Pichardo AE, Chávez-Arias D. Análisis de parámetros cinemáticos de la marcha normal. Rev Mex Ortop Traum [Internet]. 1998; 12(5):372-376.

[65] Dankloff Mora C, Rodríguez R, Fernández-Valencia R. Estudio morfofuncional de la marcha humana. J Biomecánica [Internet]. 1993;1(1):54-58. Available from: $h t t p: / / h d l . h a n d l e . n e t / 2099 / 6593$

[66] Díaz-Novo D, López-Ríos N, Montoya-Padrón A, Carvajal Fals H, et al. Evaluación preliminar de la marcha en individuos sanos. Universidad, Ciencia y Tecnología [Internet]. 2007;11(44):135-140. Available from: $h t t p: / / v e . s c i e l o . o r g / s c i e l o . p h p ? s c r i p t=s c i \_a r t t e x t \& p i$ $d=$ S1316-48212007000300005

[67] Galli M, Cimolin V, Rigoldi C, Tenore N, et al. Gait patterns in hemiplegic children with Cerebral Palsy: Comparison of right and left hemiplegia. Res Dev Disabil [Internet]. 2010;31(6):1340-1345. Available from: https://doi.org/10.1016/j.ridd.2010.07.007
[68] Spaich EG, Hinge HH, Arendt-Nielsen L, Andersen OK. Modulation of the withdrawal reflex during hemiplegic gait: Effect of stimulation site and gait phase. Clin Neurophysiol [Internet] 2006;117(11):2482-2495. Available from: https://doi.org/10.1016/j.clinph.2006.07.139

[69] Ambrose A, LeValley A, Verghese J. A comparison of communityresiding older adults with frontal and parkinsonian gaits. J Neurol Sci [Internet]. 2006;248(1-2):215-218. Available from: https://doi.org/10.1016/i.jns.2006.05.035

[70] You-Yin C, Chien-Wen C, Sheng-Huang L, Hsin-Yi L, et al. A visionbased regression model to evaluate Parkinsonian gait from monocular image sequences. Expert Syst Appl [Internet]. 2012;39(1):520-526. Available from: https://doi.org/10.1016/j.eswa.2011.07.042

[71] Minji S, Sang-Myung C, Changhong Y, Youkyung K, et al. Impacts of freezing of gait on forward and backward gait in Parkinson's Disease. Gait Posture [Internet]. 2018;61:320-324. Available from: https://doi.org/10.1016/j.gaitpost.2018.01.034

[72] Shih-Lin C, Shinn-Zong L, Chung-Chao L, Yi-Sheng S, et al. The efficacy of quantitative gait analysis by the GAITRite system in evaluation of parkinsonian bradykinesia. Parkinsonism Relat Disord [Internet]. 2006;12(7):438-442. Available from: https://doi.org/10.1016/j.parkreldis.2006.04.004

[73] Volpea D, Pavan D, Morris M, Guiotto A, et al. Underwater gait analysis in Parkinson's disease. Gait Posture [Internet]. 2017;52:8794. Available from: https://doi.org/10.1016/i.gaitpost.2016.11.019

[74] Denton AL, Hough AD, Freeman JA, Marsden JF. Effects of superficial heating and insulation on walking speed in people with hereditary and spontaneous spastic paraparesis: A randomized crossover study. Ann Phys Rehabil Med [Internet]. 2018;61(2):72-77. Available from: https://doi.org/10.1016/j.rehab.2017.12.001

[75] Rinaldi M, Ranavolo A, Conforto S, Martino G, et al. Increased lower limb muscle coactivation reduces gait performance and increases metabolic cost in patients with hereditary spastic paraparesis. Clin Biomech [Internet]. 2017;48:63-72. Available from: https://doi.org/10.1016/i.clinbiomech.2017.07.013

[76] Zhang Y, Roxburgh R, Huang L, Parsons J, et al. The effect of hydrotherapy treatment on gait characteristics of hereditary spastic paraparesis patients. Gait Posture [Internet]. 2014;39(4):1074-1079. Available from: https://doi.org/10.1016/j.gaitpost.2014.01.010

[77] McDermott A, Bolger C, Keating L, McEvoy L, et al. Reliability of three-dimensional gait analysis in cervical spondylotic myelopathy. Gait Posture [Internet]. 2010;32(4):552-558. Available from: https://doi.org/10.1016/i.gaitpost.2010.07.019

[78] Piccinini L, Cimolin V, D’Angelo MG, Crivellini M, et al. 3D gait analysis in patients with hereditary spastic paraparesis and spastic diplegia: A kinematic, kinetic and EMG comparison. Eur J Paediatr Neurol [Internet]. 2011;15(2):138-145. Available from: https://doi.org/10.1016/j.ejpn.2010.07.009

[79] Ryu T, Choi HS, Choi H, Chung MK. A comparison of gait characteristics between Korean and Western people for establishing Korean gait reference data. Int J Ind Ergon [Internet]. 2006;36(12):1023-1030. Available from: https://doi.org/10.1016/j.ergon.2006.09.013 
[80] Jung Young C, Heri B, Ngimwhichi J, Stephanie S, et al. Effects of wearing shoes on the feet: Radiographic comparison of middle-aged partially shod Maasai women's feet and regularly shod Maasai and Korean women's feet. J Foot Ankle Surg [Internet]. 2018;24(4):330335. Available from: https://doi.org/10.1016/j.fas.2017.03.012

[81] Dalgas U, Langeskov-Christensen M, Skjerbæk A, Jensen E, et al. Is the impact of fatigue related to walking capacity and perceived ability in persons with multiple sclerosis? A multicenter study. J Neurol Sci [Internet]. 2018;387:179-186. Available from: https://doi.org/10.1016/j.jns.2018.02.026

[82] Bethoux F, Varsanik JS, Chevalier TW, Halpern EF, et al. Walking speed measurement with an Ambient Measurement System (AMS) in patients with multiple sclerosis and walking impairment. Gait Posture [Internet]. 2018;61:393-397. Available from: https://doi.org/10.1016/j.gaitpost.2018.01.033

[83] Kalron A, Aloni R. Contrasting relationship between depression, quantitative gait characteristics and self-report walking difficulties in people with multiple sclerosis. Mult Scler Relat Disord [Internet]. 2018;19:1-5. Available from: https://doi.org/10.1016/j.msard.2017.10.012

[84] van den Berg MEL, Barr CJ, McLoughlin JV, Crotty M. Effect of walking on sand on gait kinematics in individuals with multiple sclerosis. Mult Scler Relat Disord [Internet]. 2017;16:15-21. Available from: https://doi.org/10.1016/i.msard.2017.05.008

[85] Kalron A, Menascu S, Dolev M, Givon U. The walking speed reserve in low disabled people with multiple sclerosis: Does it provide greater insight in detecting mobility deficits and risk of falling than preferred and fast walking speeds? Mult Scler Relat Disord [Internet]. 2017;17:202-206. Available from: https://doi.org/10.1016/j.msard.2017.08.010

[86] Pau M, Corona F, Pilloni G, Porta M, et al. Texting while walking differently alters gait patterns in people with multiple sclerosis and healthy individuals. Mult Scler Relat Disord [Internet]. 2018;19:129133. Available from: https://doi.org/10.1016/j.msard.2017.11.021

[87] Della Sala S, Spinnler H, Venneri A. Walking difficulties in patients with Alzheimer's disease might originate from gait apraxia. J Neurol Neurosurg Psychiatry [Internet]. 2004;75(2):196-201. Available from: https://www.ncbi.nlm.nih.gov/pubmed/14742586

[88] Vieira Pereira F, Ferreira de Oliveira F, Rizek Schultz R, Ferreira Bertolucci PH. Balance impairment does not necessarily coexist with gait apraxia in mild and moderate Alzheimer's disease. Arq Neuro-Psiquiatr [Internet]. 2016;74(6):450-455. Available from: https://doi.org/10.1590/0004-282×20160063

[89] Dale ML, Curtze C, Nutt JG. Apraxia of gait- or apraxia of postural transitions? Parkinsonism Relat Disord [Internet]. 2018;50:19-22. Available from: https://doi.org/10.1016/j.parkreldis.2018.02.024

[90] Hong Jin J, Maeng Je C, Seong-Jin C, Seon-Uk K, et al. Quantitative analysis of ataxic gait in patients with schizophrenia: The influence of age and visual control. Psychiatry Res [Internet]. 2007;152(23):155-164. Available from: https://doi.org/10.1016/j.psychres.2006.09.001

[91] Wen-Juh H. Reversible pseudoathetosis and sensory ataxic gait caused by cervical spondylotic myelopathy. J Clin Neurosci [Internet]. 2016;34:271-272. Available from: https://doi.org/10.1016/j.jocn.2016.08.004
[92] Siasios ID, Spanos SL, Kanellopoulos AK, Fotiadou A, et al. The Role of Gait Analysis in the Evaluation of Patients with Cervical Myelopathy: A Literature Review Study. World Neurosurg [Internet]. 2017;101:275-282. Available from: https://doi.org/10.1016/j.wneu.2017.01.122

[93] Mihara M, Miyai I, Hatakenaka M, Kubota K, et al. Sustained prefrontal activation during ataxic gait: A compensatory mechanism for ataxic stroke? Neuroimage [Internet]. 2007;37(4):1338-1345. Available from: https://doi.org/10.1016/i.neuroimage.2007.06.014

[94] Schmitz-Hübsch T, Brandt AU, Pfueller C, Zange L, et al. Accuracy and repeatability of two methods of gait analysis - GaitRiteTM und Mobility LabTM - in subjects with cerebellar ataxia. Gait Posture [Internet]. 2016;48:194-201. Available from: https://doi.org/10.1016/i.gaitpost.2016.05.014

[95] Buckley E, Mazzà C, McNeill A. A systematic review of the gait characteristics associated with Cerebellar Ataxia. Gait Posture [Internet]. 2018;60:154-163. Available from: https://doi.org/10.1016/j.gaitpost.2017.11.024

[96] Caliandro P, Iacovelli C, Conte C, Simbolotti C, et al. Trunk-lower limb coordination pattern during gait in patients with ataxia. Gait Posture [Internet]. 2017;57:252-257. Available from: https://doi.org/10.1016/j.gaitpost.2017.06.267

[97] Pearson-Dennett V, Todd G, Wilcox RA, Vogel AP, et al. History of cannabis use is associated with altered gait. Drug Alcohol Depend [Internet]. 2017;178:215-222. Available from: https://doi.org/10.1016/i.drugalcdep.2017.05.017

[98] Lambert CS, Philpot RM, Engberg ME, Johns BE, et al. Gait analysis and the cumulative gait index (CGI): Translational tools to assess impairments exhibited by rats with olivocerebellar ataxia. Behav Brain Res [Internet]. 2014;274:334-343. Available from: https://doi.org/10.1016/j.bbr.2014.08.004

[99] Schniepp R, Wuehr M, Schlick C, Huth S, et al. Increased gait variability is associated with the history of falls in patients with cerebellar ataxia. J Neurol [Internet]. 2014;261:213-223. Available from: https://doi.org/10.1007/s00415-013-7189-3

[100] Wuehr M, Nusser E, Krafczyk S, Straube A, et al. Noise-Enhanced Vestibular Input Improves Dynamic Walking Stability in Healthy Subjects. Brain Stimul [Internet]. 2016;9(1):109-116. Available from: https://doi.org/10.1016/j.brs.2015.08.017.

[101] Iwasaki S, Fujimoto C, Egami N, Kinoshita M, et al. Noisy vestibular stimulation increases gait speed in normal and in bilateral vestibulopathy. Brain Stimul [Internet]. 2018;11(4):709-715. Available from: https://doi.org/10.1016/j.brs.2018.03.005

[102] Yin M, Ishikawa K, Omi E, Saito T, et al. Small vestibular schwannomas can cause gait instability. Gait Posture [Internet]. 2011;34(1):25-28. Available from: https://doi.org/10.1016/j.gaitpost.2011.02.026

[103] Lang J, Ishikawa K, Hatakeyama K, Wong WH, et al. 3D body segment oscillation and gait analysis for vestibular disorders. Auris Nasus Larynx [Internet]. 2013;40(1):18-24. Available from: https://doi.org/10.1016/i.anl.2011.11.007 
[104] Henriksson M, Henriksson J, Bergenius J. Gait initiation characteristics in elderly patients with unilateral vestibular Impairment. Gait Posture [Internet]. 2011;33(4):661-667. Available from: https://doi.org/10.1016/i.gaitpost.2011.02.018

[105] Angunsri N, Ishikawa K, Yin M, Omi E, et al. Gait instability caused by vestibular disorders -Analysis by tactile sensor. Auris Nasus Larynx [Internet]. 2011;38(4):462-468. Available from: https://doi.org/10.1016/j.anl.2011.01.016

[106] de Souza Melo R. Gait performance of children and adolescents with sensorineural hearing loss. Gait Posture [Internet]. 2017;57:109-114. Available from: https://doi.org/10.1016/i.gaitpost.2017.05.031

[107] Hösl M, Böhm H, Eck J, Döderlein L. Positive effects of backward downhill treadmill training on spastic equinus gait. Gait Posture [Internet]. 2015; 42S: S85-S86. Available from: https://doi.org/10.1016/j.gaitpost.2015.06.156

[108] Houx L, Lempereur M, Rémy-Néris O, Brochard S. Threshold of equinus which alters biomechanical gait parameters in children. Gait Posture [Internet]. 2013;38(4):582-589. Available from: https://doi.org/10.1016/i.gaitpost.2013.01.026

[109] Gatt A, De Giorgio S, Chockalingam N, Formosa C. A pilot investigation into the relationship between static diagnosis of ankle equinus and dynamic ankle and foot dorsiflexion during stance phase of gait: Time to revisit theory? The Foot [Internet]. 2017;30:47-52. Available from: https://doi.org/10.1016/j.foot.2017.01.002

[110] Houx L, Lempereur M, Rémy-Néris O, Gross R, et al. Changes in muscle activity in typically developing children walking with unilaterally induced equinus. Clin Biomech [Internet]. 2014;29(10):1116-1124. Available from: https://doi.org/10.1016/j. clinbiomech.2014.09.015

[111] Higginson JS, Zajac FE, Neptune RR, Kautz SA, et al. Effect of equinus foot placement and intrinsic muscle response on knee extension during stance. Gait Posture [Internet]. 2006;23(1):32-36. Available from: https://doi.org/10.1016/i.gaitpost.2004.11.011

[112] Kläusler M, Speth BM, Brunner R, Tirosh O, et al. Long-term follow-up after tibialis anterior tendon shortening in combination with Achilles tendon lengthening in spastic equinus in cerebral palsy. Gait Posture [Internet]. 2017;58:457-462. Available from: https://doi.org/10.1016/j.gaitpost.2017.08.028

[113] Allet L, Armand S, Aminian K, Pataky Z, et al. An exercise intervention to improve diabetic patients' gait in a real-life Environment. Gait Posture [Internet]. 2010;32(2):185-190. Available from: https://doi.org/10.1016/i.gaitpost.2010.04.013

[114] Camargo MR, Barela JA, Nozabieli AJL, Mantovani AM, et al. Balance and ankle muscle strength predict spatiotemporal gait parameters in individuals with diabetic peripheral neuropathy. Diabetes Metab Syndr [Internet]. 2015;9(2):79-84. Available from: https://doi.org/10.1016/j.dsx.2015.02.004

[115] Fernando M, Crowther R, Lazzarini P, Sangla K, et al. Biomechanical characteristics of peripheral diabetic neuropathy: A systematic review and meta-analysis of findings from the gait cycle, muscle activity and dynamic barefoot plantar pressure. Clin Biomech [Internet]. 2013;28(8):831-845. Available from: https://doi.org/10.1016/j.clinbiomech.2013.08.004
[116] Sawacha Z, Gabriella G, Cristoferi G, Guiotto A, et al. Diabetic gait and posture abnormalities: A biomechanical investigation through three dimensional gait analysis. Clin Biomech [Internet]. 2009;24(9):722-728. Available from: https://doi.org/10.1016/j.clinbiomech.2009.07.007

[117] Khalaf K, Al-Angari HM, Khandoker AH, Lee S, et al. Gait alterations in the UAE population with and without diabetic complications using both traditional and entropy measures. Gait Posture [Internet]. 2017;58:72-77. Available from: https://doi.org/10.1016/i.gaitpost.2017.07.109

[118] Allet L, Armand S, de Bie RA, Golay A, et al. Reliability of diabetic patients' gait parameters in a challenging environment. Gait Posture [Internet]. 2008;28(4):680-686. Available from: https://doi.org/10.1016/j.gaitpost.2008.05.006

[119] Jin-Hyuck P. The effects of plantar perception training on balance and falls efficacy of the elderly with a history of falls: A singleblind, randomized controlled trial. Arch Gerontol Geriatr [Internet]. 2018;77:19-23. Available from: https://doi.org/10.1016/j.archger.2018.03.014

[120] Herman T, Giladi N, Gurevich T, Hausdorff JM. Gait instability and fractal dynamics of older adults with a "cautious" gait: why do certain older adults walk fearfully? Gait Posture [Internet]. 2005;21(2):178-185. Available from: https://doi.org/10.1016/i.gaitpost.2004.01.014

[121] Tsai Y-J, Lin S-I. Older adults adopted more cautious gait patterns when walking in socks than barefoot. Gait Posture [Internet]. 2013;37(1):88-92. Available from: https://doi.org/10.1016/j.gaitpost.2012.06.034

[122] Liang C-K, Chou M-Y, Peng L-N, Liao M-C, et al. Gait speed and risk assessment for falls among men aged 80 years and older: A prospective cohort study in Taiwan. Eur Geriatr Med [Internet]. 2014;5(5):298-302. Available from: https://doi.org/10.1016/j. eurger.2014.06.034

[123] Balasubramanian CK, Clark DJ, Gouelle A. Validity of the Gait Variability Index in older adults: Effect of aging and mobility impairments. Gait Posture [Internet]. 2015;41(4):941-946. Available from: https://doi.org/10.1016/j.gaitpost.2015.03.349

[124] Spaulding SJ, Patla AE, Flanagan J, Elliott DB, et al. Waterloo Vision and Mobility Study: Normal gait characteristics during dark and light adaptation in individuals with age-related maculopathy. Gait Posture [Internet]. 1995;3(4):227-235. Available from: https://doi.org/10.1016/0966-6362(96)82852-9

[125] Fan Y, Li Z, Han S, Lv C, et al. The influence of gait speed on the stability of walking among the elderly. Gait Posture [Internet]. 2016;47:31-36. Available from: https://doi.org/10.1016/j.gaitpost.2016.02.018

[126] Cruz-Jimenez M. Normal Changes in Gait and Mobility Problems in the Elderly. Phys Med Rehabil Clin N Am [Internet]. 2017;28(4):713725. Available from: https://doi.org/10.1016/i.pmr.2017.06.005

[127] Auvinet B, Touzard C, GoëbV. Gait instability out-patients consultation in the elderly: Interests of simple and dual task gait analysis. Ann Phys Rehabil Med [Internet]. 2015;58:e155. Available from: https://doi.org/10.1016/j.rehab.2015.07.368 
[128] Hirose D, Ishida K, Nagano Y, Takashi T, et al. Posture of the trunk in the sagittal plane is associated with gait in community-dwelling elderly population. Clin Biomechs [Internet]. 2004;19(1):57-63. Available from: https://doi.org/10.1016/i.clinbiomech.2003.08.005

[129] Leigh RJ, Osis ST, Ferber R. Kinematic gait patterns and their relationship to pain in mild-to-moderate hip osteoarthritis. Clin Biomechs [Internet]. 2016;34:12-17. Available from: https://doi.org/10.1016/j.clinbiomech.2015.12.010

[130] Smith JA, Gordon J, Kulig K. The influence of divided attention on walking turns: Effects on gait control in young adults with and without a history of low back pain. Gait Posture [Internet]. 2017;58:498-503. Available from: https://doi.org/10.1016/j.gaitpost.2017.09.019

[131] O'Connell M, Farrokhi S, Fitzgerald GK. The role of knee joint moments and knee impairments on self-reported knee pain during gait in patients with knee osteoarthritis. Clin Biomechs [Internet]. 2016;31:40-46. Available from: https://doi.org/10.1016/j.clinbiomech.2015.10.003

[132] Sawa R, Doi T, Misu S, Saito T, et al. The severity and number of musculoskeletal pain associated with gait in community-dwelling elderly individuals. Gait Posture [Internet]. 2017;54:242-247. Available from: https://doi.org/10.1016/j.gaitpost.2017.03.013

[133] Chen G, Nie Y, Xie J, Cao G, et al. Gait Analysis of Leg Length Discrepancy-Differentiated Hip Replacement Patients With Developmental Dysplasia: A Midterm Follow-Up. J Arthroplast [Internet]. 2018;33(5):1437-1441. Available from: https://doi.org/10.1016/j.arth.2017.12.013

[134] Beresford MW, Cleary AG. Evaluation of a limping child. Curr Paediatr [Internet]. 2005;15(1):15-22. Available from: https://doi.org/10.1016/j.cupe.2004.10.004

[135] Khamis S, Carmeli E. Relationship and significance of gait deviations associated with limb length discrepancy: A systematic review. Gait Posture [Internet]. 2017;57:115-123. Available from: https://doi.org/10.1016/j.gaitpost.2017.05.028

[136] Khamis S, Carmeli E. The effect of simulated leg length discrepancy on lower limb biomechanics during gait. Gait Posture [Internet]. 2018;61:73-80. Available from: https://doi.org/10.1016/i.gaitpost.2017.12.024

[137] Chopra S, Crevoisier X. Preoperative gait asymmetry in end-stage unilateral ankle osteoarthrosis patients. Foot Ankle Surg [Internet]. 2019;25(3):298-302. Available from: https://doi.org/10.1016/j.fas.2017.12.004

[138] Vasudevan PN, Vaidyalingam KV, Nair PB. Can trendelenburg’s sign be positive if the hip is normal? J Bone Joint Surg [Br] [Internet]. 1997;79-B(3):462-466. Available from: https://doi.org/10.1302/0301-620X.79B3.0790462
[139] Physiopedia USA, Trendelenburg Gait [Internet]. 2021; Available from: https://www.physio-pedia.com/Trendelenburg_Gait

[140] Pai VS. Significance of the Trendelenburg test in total hip arthroplasty influence of lateral approaches. J Arthroplast [Internet]. 1996;11(2):174-179. Available from: https://doi.org/10.1016/S0883-5403(05)80013-0

[141] Petrofsky JS. The use of electromyogram biofeedback to reduce Trendelenburg gait. Eur J Appl Physiol [Internet].2001;85(5):491-495. Available from: https://doi.org/10.1007/s004210100466

[142] Gilliss AC, Swanson RL, Janora D, Venkataraman V. Use of Osteopathic Manipulative Treatment to Manage Compensated Trendelenburg Gait Caused by Sacroiliac Somatic Dysfunction. JOM[Internet]. 2010;110(3):81-86. Available from: https://doi.org/10.7556/jaoa.2010.110.2.81

[143] Koutakis P, Johanning JM, Haynatzki G, Myers SA, et al. Abnormal joint powers before and after the onset of claudication symptoms. J Vasc Surg [Internet]. 2010;52(2):340-347. Available from: https://doi.org/10.1016/j.jvs.2010.03.005

[144] Zijlstra W. Assessment of spatio-temporal parameters during unconstrained walking. Eur J Appl Physiol [Internet]. 2004;92:3944. Available from: https://doi.org/10.1007/s00421-004-1041-5

[145] Öberg T, Karsznia A, Öberg K. Basic gait parameters: Reference data for normal subjects, 10-79 years of age. J Rehabil Res Dev [Internet]. 1993;30(2):210-223. Available from: https://www.rehab.research.va. gov/jour/93/30/2/pdf/oberg.pdf

[146] Chung M-J, Wang M-J J. The change of gait parameters during walking at different percentage of preferred walking speed for healthy adults aged 20-60 years. Gait Posture [Internet]. 2010;31(1):131-135. Available from: https://doi.org/10.1016/i.gaitpost.2009.09.013

[147] Stolze H, Kuhtz-Buschbeck JP, Mondwurf C, Jöhnk K, et al. Retest reliability of spatiotemporal gait parameters in children and adults. Gait Posture [Internet]. 1998;7(2):125-130. Available from: https://doi.org/10.1016/S0966-6362(97)00043-X

[148] Kirtley C. Clinical Gait Analysis: Theory and Practice. China: Elsevier, Churchill Livingstone; 2006. 316p.

[149] Erhart-Hledik JC, Favre J, Andriacchi TP. New insight in the relationship between regional patterns of knee cartilage thickness, osteoarthritis disease severity, and gait mechanics. J Biomech [Internet]. 2015;48(14):3868-3875. Available from: https://doi.org/10.1016/i.jbiomech.2015.09.033 